\title{
Early Middle Devonian conodont faunas (Eifelian, costatus-kockelianus zones) from the Roberts Mountains and adjacent areas in central Nevada
}

\author{
StANISLAVA VODRÁŽKOVÁ, GILBERT KLAPPER \& MiCHAEL A. MURPHY
}

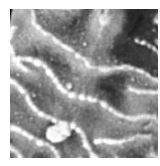

\begin{abstract}
Conodont faunas from the uppermost part of the Coils Creek Member of the McColley Canyon Formation and primarily the lower part of the Denay Limestone (Middle Devonian, Eifelian) from the northern Roberts Mountains and adjacent central Nevada areas are the subjects of the present study. Four new species from the Denay Limestone (Eifelian, costatus and australis zones) are described herein: Polygnathus salixensis sp. nov., P. holynensis sp. nov., $P$. robertsensis sp. nov. and $P$. damelei $\mathrm{sp}$. nov. These species add to the biostratigraphic resolution and characterization of the costatus and australis zones. The basal Denay Limestone in the northern Roberts Mountains is in the upper part of the costatus Zone, which directly overlies the upper Coils Creek Member in the serotinus Zone. Thus, the patulus and partitus zones are missing in this area. To the south in the northern Antelope Range and the northern Hot Creek Range, the partitus Zone sits directly on the serotinus Zone with the patulus Zone missing. Key words: Middle Devonian, conodont biostratigraphy, Nevada, Roberts Mountains.
\end{abstract}

\begin{abstract}
VODRÁŽKOVÁ, S., KlAPPER, G. \& MURPHY, M.A. 2011. Early Middle Devonian conodont faunas (Eifelian, costatus-kockelianus zones) from the Roberts Mountains and adjacent areas in central Nevada. Bulletin of Geosciences 86(4), 737-764 (14 figures, 3 appendices). Czech Geological Survey, Prague. ISSN 1214-1119. Manuscript received June 27, 2011; accepted in revised form August 18, 2011; published online November 9, 2011; issued November 16, 2011.

Stanislava Vodrážková, Czech Geological Survey, P.O.B. 85, 11821 Prague 1, Czech Republic; stana.vodrazkova@seznam.cz・Gilbert Klapper, Earth and Planetary Sciences, Northwestern University, Evanston, IL 60208,USA; g-klapper@northwestern.edu • Michael A. Murphy, University of California, Riverside, 900 University Ave., Riverside, CA 92521,USA; mamurphy680@gmail.com
\end{abstract}

\begin{abstract}
Middle Devonian conodonts (Eifelian) from the Roberts Mountains (Nevada) and adjacent areas are the subject of the present research. The conodont faunas discussed come from the uppermost part of the Coils Creek Member (Murphy \& Gronberg 1970) of the McColley Canyon Formation (Carlisle et al. 1957, Johnson 1966) and the lower part of the Denay Limestone (Johnson 1966, Murphy 1977). These two units crop out throughout the Roberts Mountains as well as other ranges in the limestone belt of central Nevada and by virtue of their contrasting lithologies the boundary between them is easily mapped.
\end{abstract}

\section{Geological setting \\ Coils Creek Member, McColley Canyon Formation}

The Coils Creek Member, the uppermost member of the McColley Canyon Formation (Murphy \& Gronberg 1970), has been mapped at Red Hill in the northern Simpson Park
Range, throughout the Roberts Mountains, in the southern Sulphur Springs Range, at the Lone Mountain, in the northern Antelope Range, and in the northern Hot Creek Range (Fig. 1). Historically, the McColley Canyon Formation has been treated as a deepening upward sequence with some fluctuations in all members and with the Kobeh (basal member of the formation) showing the most wave-generated structures, the Bartine (the middle member) fewer, and the Coils Creek few, if any, such structures. The Coils Creek Member consists of rather uniform, medium- to thick-bedded, medium- to light-gray, very fine-grained limestones, generally with very few identifiable macrofossils (Murphy \& Gronberg 1970). Those authors interpreted the depositional environment of this member as outer shelf below storm wave base in relatively deep, quiet, but well-aerated water.

\section{Denay Limestone}

The name Denay Limestone was introduced by Johnson (1966) for then unnamed Middle Devonian strata in the 


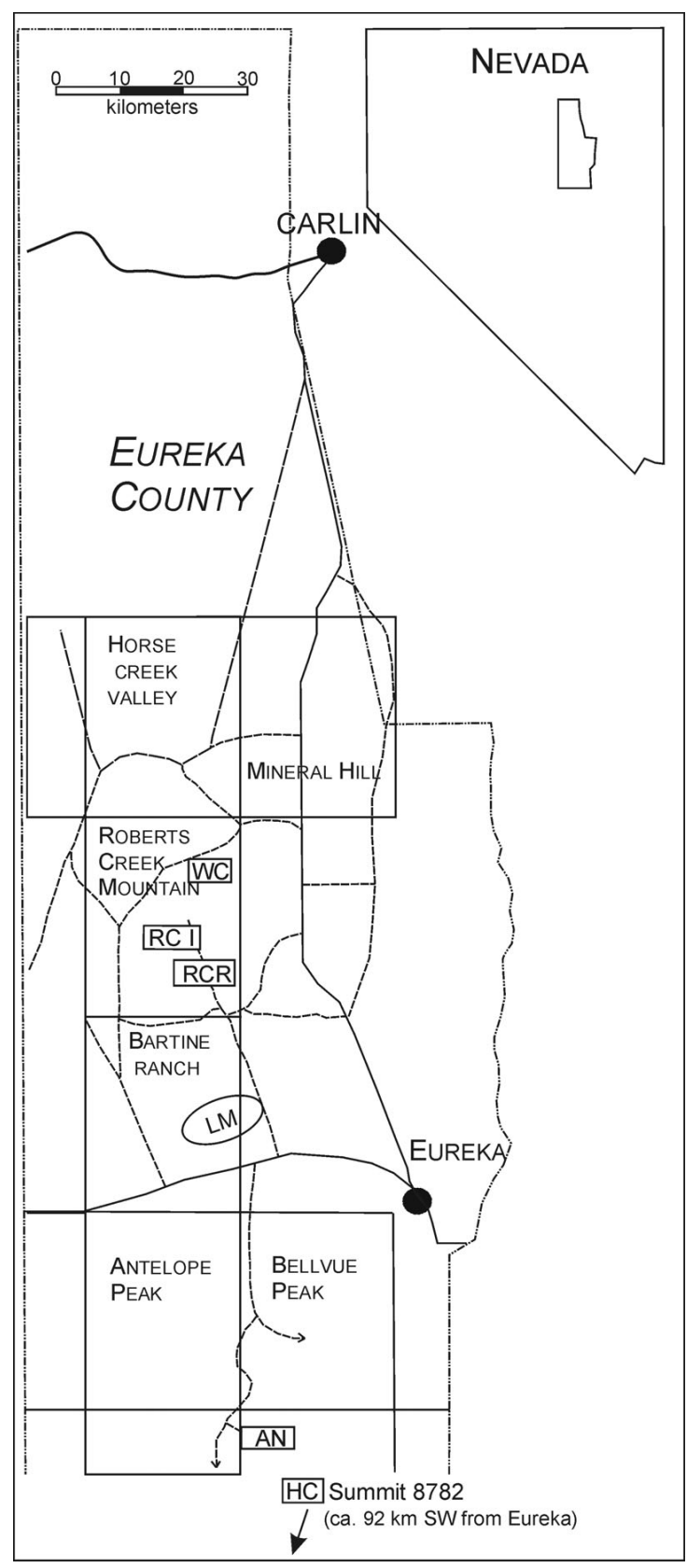

Figure 1. Schematic map showing locations of conodont localities in the northern Roberts Mountains and Eureka County, central Nevada. Abbreviations: WC - Willow Creek (see Fig. 2B for detailed map of Willow Creek sections), RC I - Roberts Creek, RCR - Roberts Creek Ranch, LM - Lone Mountain, AN - northern Antelope Range, HC - Hot Creek. Modified after Murphy \& Gronberg (1970).

northern Roberts Mountains and northern Simpson Park Range lying between the McColley Canyon Formation and the Devils Gate Formation (Nolan et al. 1956). Morgan (1974, unpublished thesis), Murphy \& Morgan (1974), and especially Murphy (1977) studied the lithologic development of the Denay Limestone. In comparison to rather uniform development of the underlying Coils Creek Member, the lithologic development of the Denay Limestone is much more diverse. Murphy (1977) informally divided the upward shoaling sequence of the Denay Limestone into three parts on the basis of the percentage of coarse-grained limestone beds (Fig. 2). The conodont faunas studied herein come from the first two parts of the Denay Limestone. The lower part of the formation is according to Murphy (1977) comprised of laminated, thin-bedded lime-mudstones with interbeds of graded or massive bioclastic packstones, grainstones and occasionally also intraformational breccias (debris flows deposits). The middle part of the formation is characterized by thick-bedded, coarse-grained wackestones, packstones, grainstones, rudstones and floatstones with abundant coral, stromatoporoid and brachiopod faunas (gravity flow deposits) interbedded with thin beds of laminated, fine-grained limestones. Murphy (1977) and Murphy \& Morgan (1974) interpreted the depositional environment of the Denay Limestone as deep-water, shelf-slope, and basinal deposits. The first author studied the boundary between the Coils Creek Member and the Denay Limestone in the northern Roberts Mountains and northern Simpson Park Range in an attempt to characterize its nature and recorded a number of features suggesting an unconformity in most of the study area (abrupt lithological change, erosional contacts).

\section{Previous studies on Lower and Middle Devonian (Emsian-Eifelian) conodont faunas from the Roberts Mountains and adjacent areas}

The first study on conodont faunas from Lower and Middle Devonian strata of central Nevada was published by Clark \& Ethington (1966), who described and figured a species of Polygnathus from the Lone Mountain section (Fig. 1), identified as $P$. linguiformis Hinde (1879). The Lone Mountain specimen illustrated on their plate 84, fig. 7, was later included by Klapper \& Johnson (1975, p. 74) within their new Emsian species, P. laticostatus. [The other specimen identified as $P$. linguiformis by Clark \& Ethington (1966, pl. 84, fig. 9) is indeed that species, but is from the Middle Devonian Simonson Formation in the Confusion Range, Utah.] Klapper \& Johnson (1975, figs 3, 4) described an evolutionary sequence within Polygnathus from the McColley Canyon Formation and basal Denay Limestone in the Lone Mountain section and demonstrated the correlative value of species within this sequence with strata elsewhere in Nevada, Canada, Australia, Spain, and Germany. Conodonts from Red Hill (a short distance NW of the Roberts Mountains) were studied by Morgan (1974, unpublished thesis), who recognized two different conodont faunal assemblages in the Coils Creek Member and Denay Limestone (see below). Klapper (1977a) studied upper Emsian and Eifelian conodont biostratigraphy, recognizing the 

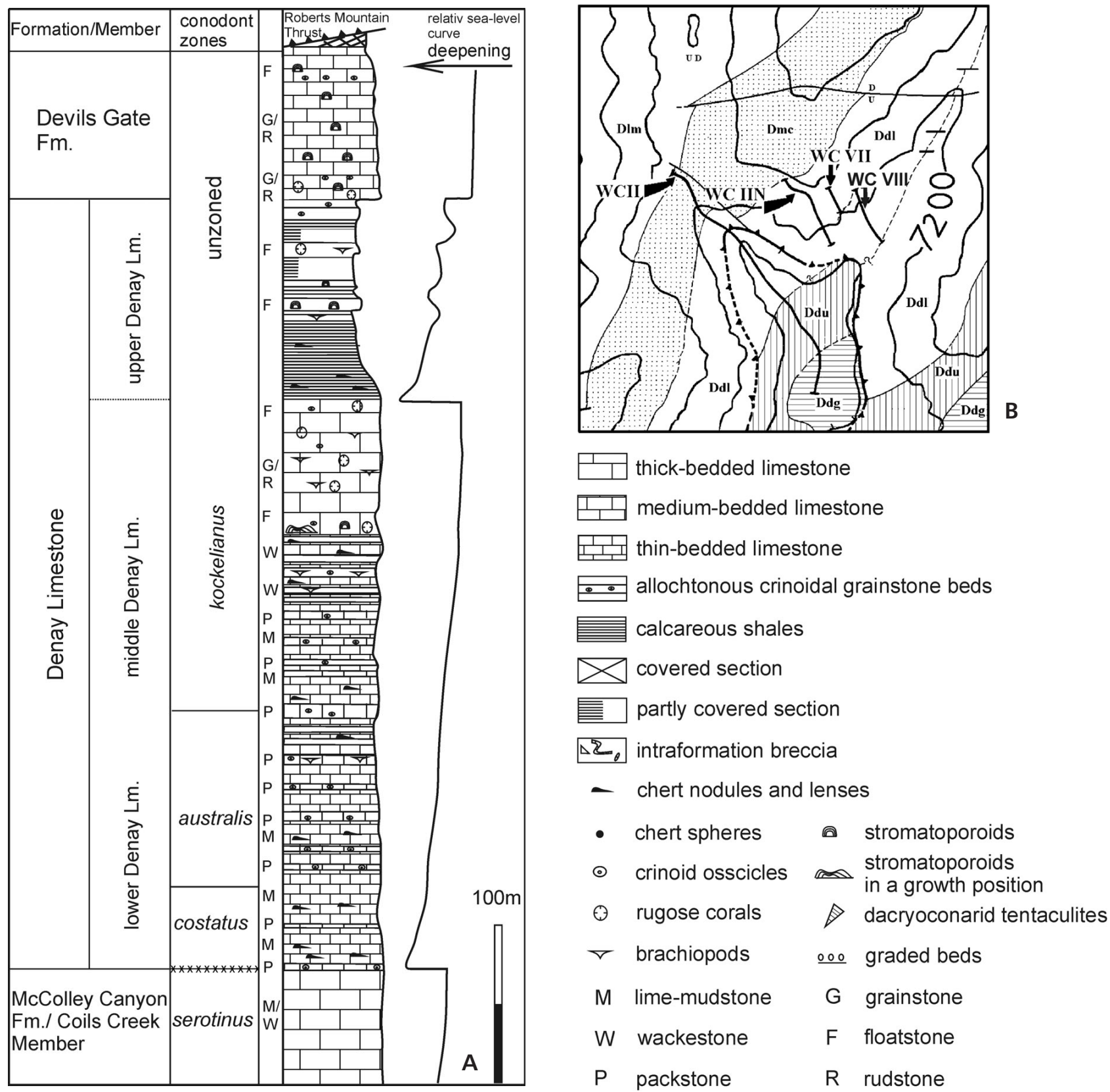

Figure 2. A - Willow Creek composite section with reconstructed relative sea-level curve. Mappable beds were followed between the partial sections (WC II, IIN, VII, VIII) in order to compile the composite. Slightly modified after Murphy (1977). B • Detailed map of Willow Creek with the position of WC II and WC IIN indicated. Sections WC VII and VIII, which are also indicated, were not a subject of our study.

serotinus, costatus, australis and kockelianus zones in central Nevada sections and discussed possible explanations for the missing patulus Zone (see below). Klapper \& Johnson (1980), Klapper in Johnson et al. (1980) and in Johnson et al. (1996) identified conodonts from the northern Antelope Range (concentrating on section $\mathrm{V}$ in the latter paper), in which evidence for the conodont succession from the serotinus to the kockelianus zones was presented. The revision of the 1996 conodont collections by Klapper and critical new collections from section V by C.A. Sandberg re- vealed an absence of the patulus Zone in northern Antelope Range section V [Sandberg \& Klapper in Elrick et al. 2009, p. 171, where the partitus Zone (sample VH6 in Johnson et al. 1996, table 2)] lies only $0.3 \mathrm{~m}$ of an unsampled shale interval above the serotinus Zone (sample VH5); see also Sandberg in Morrow 2007). Conodonts from the Givetian varcus Zone of the Denay Limestone at Willow Creek (WC II) were described by Ziegler et al. (1976).

Pedder (2010) studied the succession of rugose coral faunas from the serotinus Zone to the costatus Zone and 


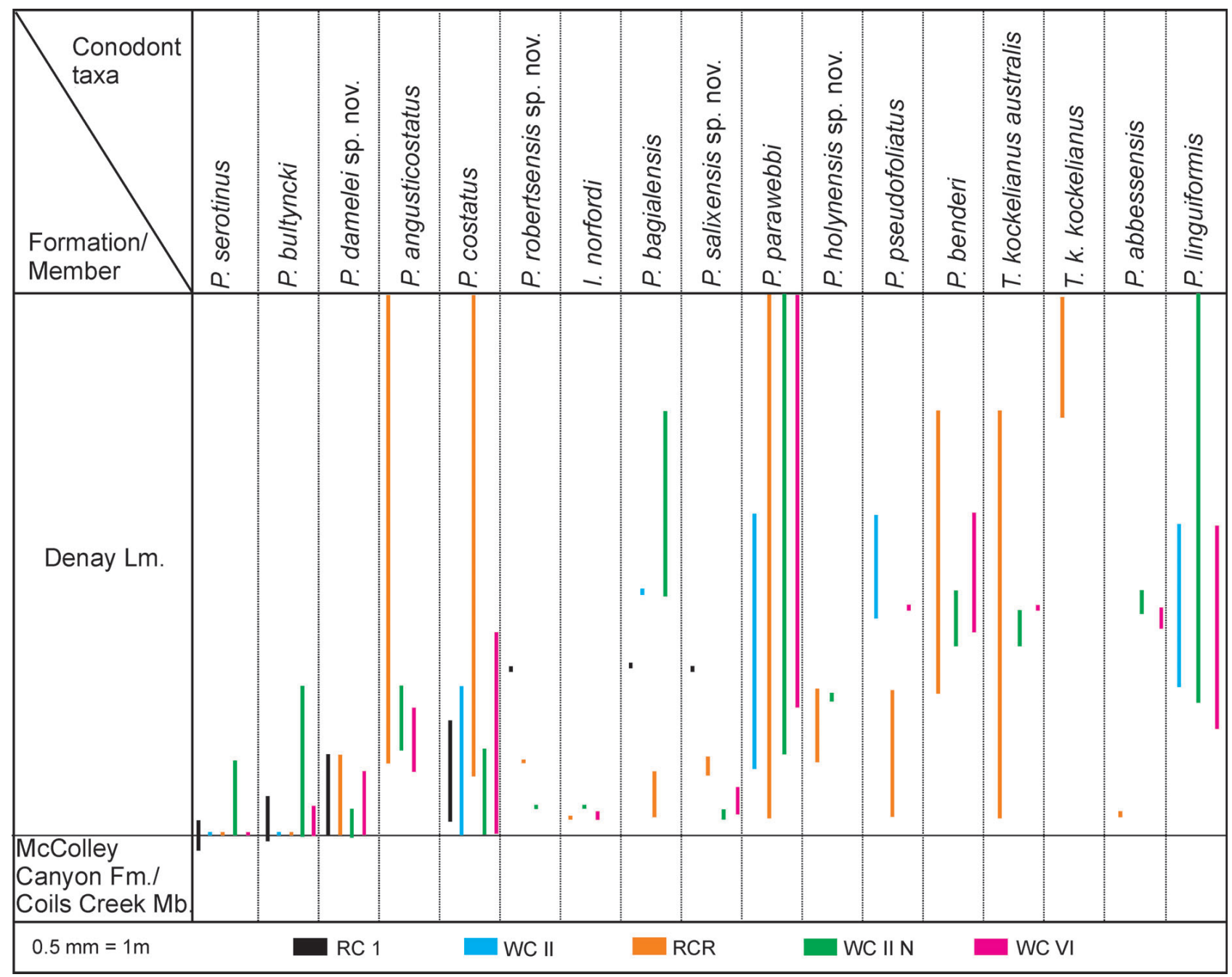

Figure 3. Stratigraphic distribution of conodont species in the Coils Creek Member and the Denay Limestone at individual sections.

provided new data from the northern Antelope Range and the southern Sulphur Spring Range.

\section{Previous studies on the missing record in the Roberts Mountains}

Johnson (1962) described a significant faunal break between the Lower Devonian Eurekaspirifer pinyonensis Zone (faunal intervals 10-12 sensu Johnson 1977, gronbergi and inversus zones) and Middle Devonian circula Zone (costatus-kockelianus zones, faunal units FI 13 and FI 15 sensu Johnson 1977), which according to Johnson (1966) also coincides with a lithologic break between these zones (argillaceous limestones of the pinyonensis Zone and siliceous platy gray limestones of the Leptathyris circula Zone). Murphy \& Gronberg (1970) recorded the Elythyna faunal assemblage of the pinyonensis Zone (faunal interval 14 sensu Johnson 1977, serotinus Zone) in the upper part of
Coils Creek Member and thus reduced the missing record. Although a faunal break between the Coils Creek Member of the McColley Canyon Formation and the Denay Limestone in the northern Roberts Mountains was apparent (Murphy 1977), no conclusive evidence in terms of exact biostratigraphic data existed then. Morgan (1974, unpublished thesis) recognized two different conodont assemblages in the upper Coils Creek Member and lower Denay Limestone in the Red Hill area and regarded the abrupt upper limit of the first and lower limit of the succeeding assemblage as a result of paraconformity, following the ideas of Johnson (1962). Klapper (1977a, pp. 44, 45) recorded the absence of the patulus Zone in central Nevada, attributing it either to a biostratigraphic hiatus corresponding to physical unconformity or, in the case of Lone Mountain, to sampling deficiencies. The patulus Zone was later identified in the northern Hot Creek Range (Johnson et al. 1986, table 8; Klapper \& Ziegler 1979) and in the crinoidal member of the Sadler Ranch Formation at Modoc Peak (Johnson 
\& Murphy 1984), but these occurrences may be better interpreted now as belonging to the partitus Zone. The main evidence for the patulus Zone was from the Summit 8782 section in the northern Hot Creek Range. That section (Johnson et al. 1986, table 8) shows a lower fault block with the serotinus, partitus, and costatus zones overlain by an upper fault block with the serotinus, supposedly patulus, and costatus zones. We suspect that the upper block should be the same as the lower fault block and thus doubt the identification of the patulus Zone here because that zone is clearly missing in the northern Antelope section V. In summary, the patulus Zone is probably absent in the known outcrop areas in central Nevada that expose the contact of the Denay Limestone on the Coils Creek Member of the McColley Canyon Formation. Johnson \& Murphy (1984, p. 1353) noted that the base of the Denay Limestone is in but not at the base of the costatus Zone. The missing interval in the northern Antelope Range was recently discussed by Pedder (2010).

\section{Results}

\section{Missing record in the Roberts Mountains and adjacent areas}

The faunas from the following sections were studied (Fig.1): Roberts Creek (RC1), Roberts Creek ranch (RCR) and three sections at Willow Creek (WC II, WC II N and WC VI). Additionally, faunas from northern Antelope section V and the Hot Creek Summit 8782 section are included in the Systematic Paleontology section. In the northern Antelope and Hot Creek sections the basal Eifelian partitus Zone intervenes between the underlying Emsian serotinus Zone and the overlying Eifelian costatus Zone, unlike the northern Roberts Mountains where there is no evidence for the patulus and partitus zones.

As Fig. 3 indicates, Polygnathus serotinus and P. bultyncki were recorded in the uppermost beds of the Coils Creek Member. Neither of these species is zonally diagnostic. P. serotinus (nominal species of the serotinus Zone) is long ranging, with the range being mostly recorded from the serotinus Zone to the partitus Zone (e.g., Belka et al. 1997, Berkyová 2009, Mawson 1987, Weddige 1977) and the lower part of the costatus Zone (Johnson et al. 1996, Klapper 1977a, Klapper et al. 1978, Lane \& Ormiston 1979). The range of $P$. bultyncki is similar to that of $P$. serotinus occurring commonly from the serotinus Zone to the lower costatus Zone.

The lowermost part of the Denay Limestone in the northern Roberts Mountains yielded Polygnathus costatus, $P$. serotinus and $P$. bultyncki, thus indicating the costatus Zone. Neither the nominal species nor the accompanying faunas of the patulus and partitus zones have been found, which indi- cates absence of these conodont zones in the northern Roberts Mountains. In the lower Denay Limestone (interval from $\mathrm{ca}$ $5 \mathrm{~m}$ to $20 \mathrm{~m}$ ), new faunal elements appear (Figs 3-5), e.g. $P$. angusticostatus, $P$. bagialensis, $P$. parawebbi, $P$. pseudofoliatus and Tortodus kockelianus australis representing the australis Zone. The occurrences of these species low in the Denay Limestone considerably reduce the thickness of the costatus Zone (5 $\mathrm{m}$ in the RCR section, Fig. 5). The differences in sedimentary rates and patterns at individual sections might partly account for the reduction of thickness of the costatus Zone. However, based on evidence for the missing patulus and partitus zones and the physical character of the Coils Creek/Denay Limestone boundary, the absence of these two zones and also of the lower part of the costatus Zone due to physical unconformity appears to be most probable.

\section{Summary and concluding remarks}

Conodonts from the top of the Coils Creek and the base of the Denay Limestone of northern Roberts Mountains and adjacent areas (central Nevada) were the subject of the recent study. Specifications of stratigraphic distribution and geographic occurrences of important conodont species are given here: $P$. bagialensis and $P$. benderi have been recorded from central Nevada for the first time. The upper range of $P$. costatus has been recorded as high as in the basal kockelianus Zone, which represents its highest published occurrence. Four new species are described herein: Polygnathus holynensis sp. nov., Polygnathus salixensis sp. nov. (costatus Group), Polygnathus damelei sp. nov. and Polygnathus robertsensis sp. nov. (robertsensis Group). Exact biostratigraphic data constrains precisely the conodont zones of the top of the Coils Creek Member of the McColley Canyon Formation and the base of the Denay Limestone. At all Roberts Mountains sections studied so far, the higher part of the Eifelian costatus Zone (inferred from the conodont associations, as shown in Fig. 3) in the lower Denay lies directly on the Emsian serotinus Zone in the upper Coils Creek. It is concluded that the patulus and partitus zones, as well as the lower part of the costatus Zone, are absent in the sequences in the northern Roberts Mountains. In the northern Antelope Range and the northern Hot Creek Range to the south, however, the partitus Zone intervenes between the costatus Zone above and the serotinus Zone below, with the patulus Zone missing.

\section{Systematic section}

Photography of the specimens was made in the Paleontological department of Natural History Museum (National Museum, Prague) using the Olympus SZX-12 (e.g., Fig. 10), Charles University in Prague using the JEOL 


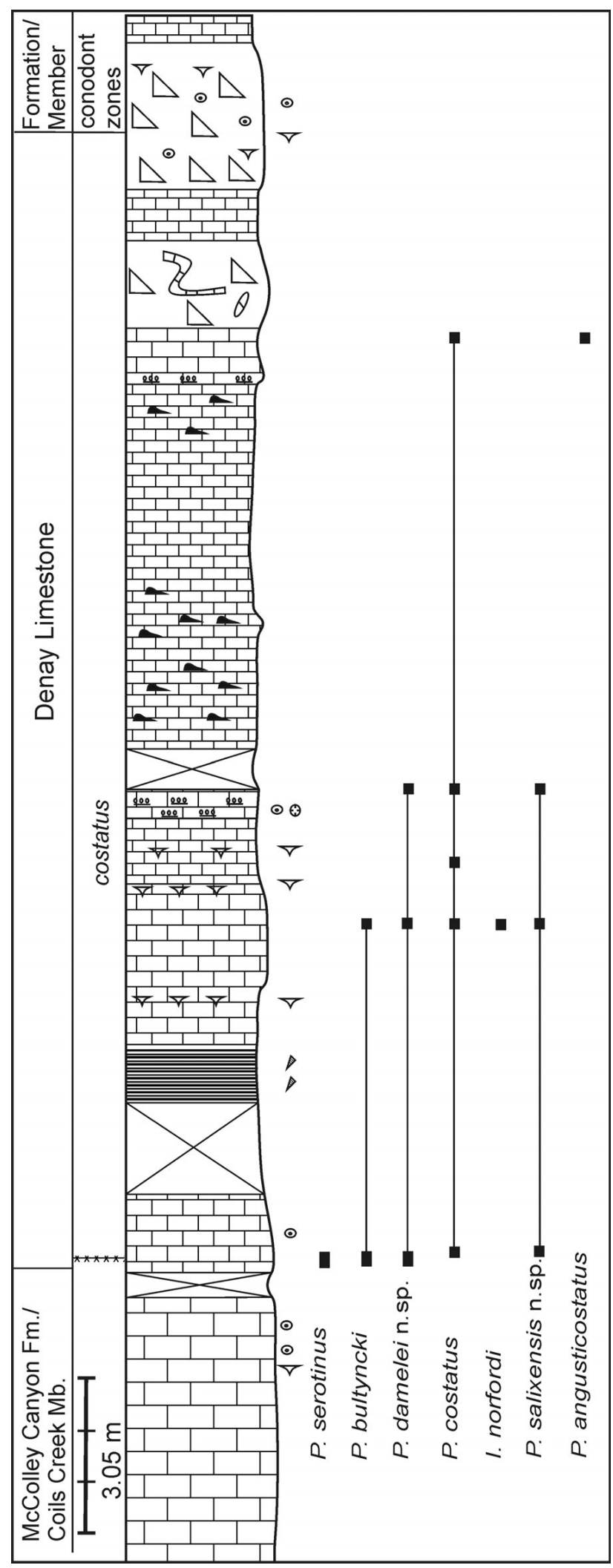

Figure 4. Lithological column of Willow Creek VI section with conodont species ranges. See legend in Fig. 2.
JSM-6380 (Figs 6F-H), Department of Earth Sciences, University of California at Riverside using a Leica MZ16 microscope mounted with a Leica DFC420 camera (e.g., Fig. 11A, C, J - lateral views) and Department of Geoscience, University of Iowa using a Leitz Aristophot setup mounted with a Canon 50D camera (e.g., Fig. 9B, C), and more recently with a Visionary Digital BK Lab System (http://www.visionarydigital.com/IntegratedSystems2.html) mounted with a Canon 7D digital camera (e.g., Fig. 8C-G, I). All the photographs, except for Figs $6 \mathrm{~J}-\mathrm{O}, 8 \mathrm{C}-\mathrm{I}$, and 9, were stacked using the CombineZP software (http://www.hadleyweb.pwp.blueyonder.co.uk/). The specimens studied are deposited in the collection of Michael A. Murphy in the University of California, Riverside (UCR type numbers), of Stanislava Vodrážková in the Czech Geological Survey (SB3-SB5), and at the University of Iowa, Iowa City (SUI type numbers).

We recognize a costatus Group of species comprised of Polygnathus costatus Klapper, 1971, P. holynensis sp. nov., $P$. salixensis sp. nov., P. partitus Klapper, Ziegler \& Mashkova, 1978, P. patulus Klapper, 1971, and P. gilklapperi Mawson \& Talent, 1994. All of these are formally described herein except for P. partitus and P. patulus, which are listed in Appendix 1 that provides critical literature references to diagnoses and illustrations. In this paper, we elevate $P$. costatus, $P$. partitus, and $P$. patulus to the species level as the degree of their differences justifies this action. The three taxa were formerly treated as subspecies of $P$. costatus. We also recognize a robertsensis Group of species comprised of $P$. robertsensis sp. nov., $P$. damelei sp. nov., $P$. zieglerianus Weddige, 1977, P. pinguis Weddige, 1977, and $P$. aff. $P$. pinguis. To be consistent in our taxonomic practice, we elevate $P$. pinguis to the species level and no longer treat it as a subspecies of $P$. linguiformis Hinde, 1879.

As to terminology in the diagnoses and descriptions, adcarinal grooves differ from adcarinal troughs in that the grooves are either equant or deeper than they are wide and the troughs are wider than they are deep.

\section{Genus Polygnathus Hinde, 1879}

Type species. - Polygnathus dubius Hinde, 1879.

\section{Polygnathus costatus Klapper, 1971}

Figure 6A-I, K-L

1971 Polygnathus costatus costatus subsp. nov.; Klapper, p. 63 , pl. 1 , figs $30-36$; pl. 2, figs $1-7$ [figs $5-7=$ holotype, reillustrated here on Fig. 6L].

1973 Polygnathus costatus costatus Klapper, 1971. Klapper in Ziegler, pp. 347, 348, Polygnathus - plate 1 , fig. 3 [reillustration of holotype; synonymy]. 


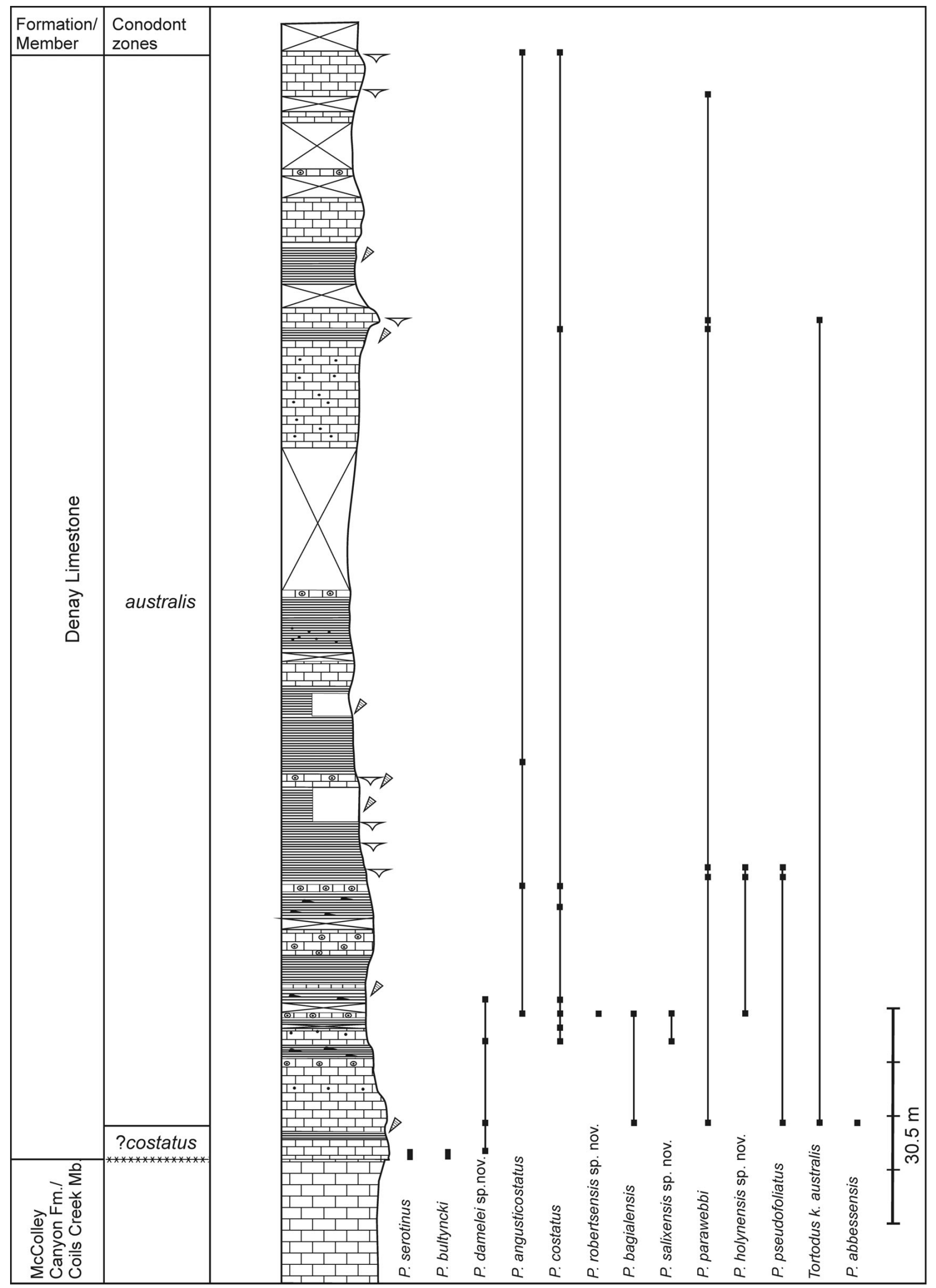

Figure 5. Lithological column of Roberts Creek Ranch section with conodont species ranges. See legend in Fig. 2. 


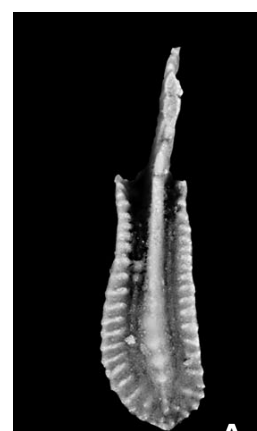

A
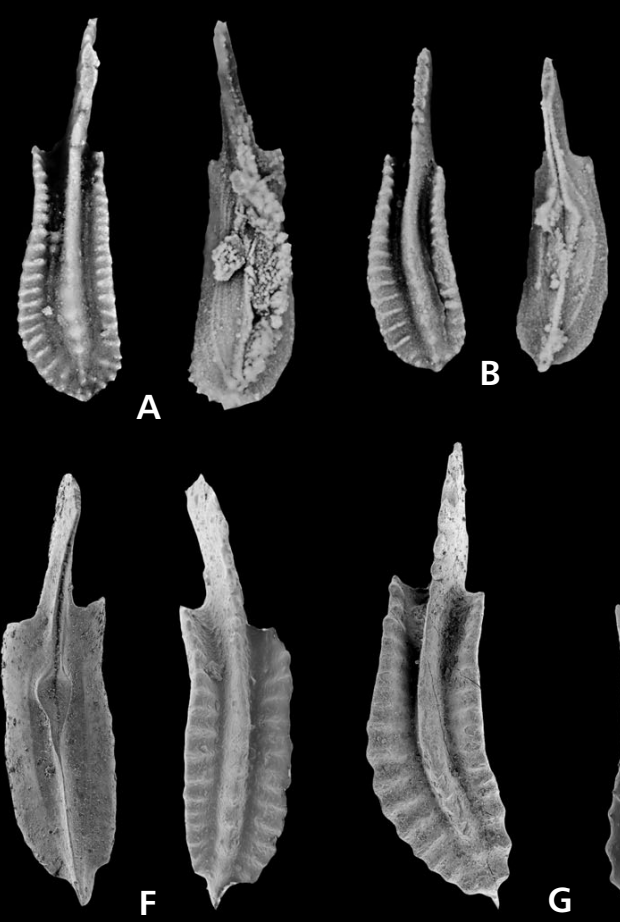

G
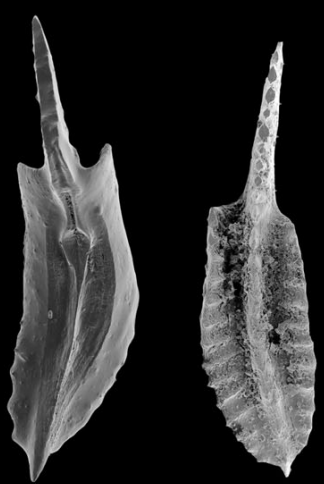

$\mathbf{H}$

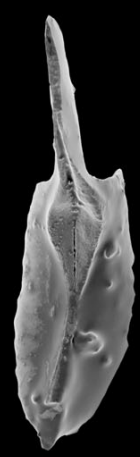

D

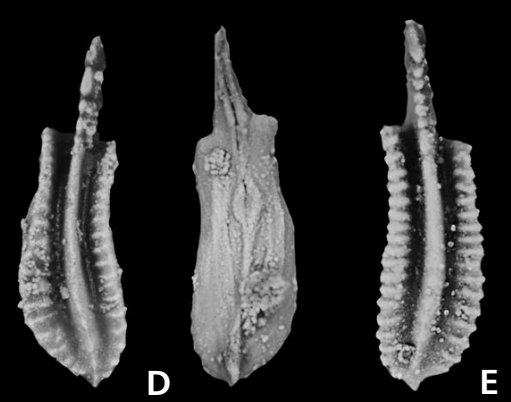

E

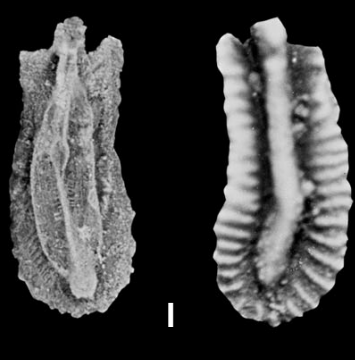

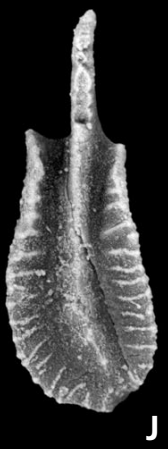
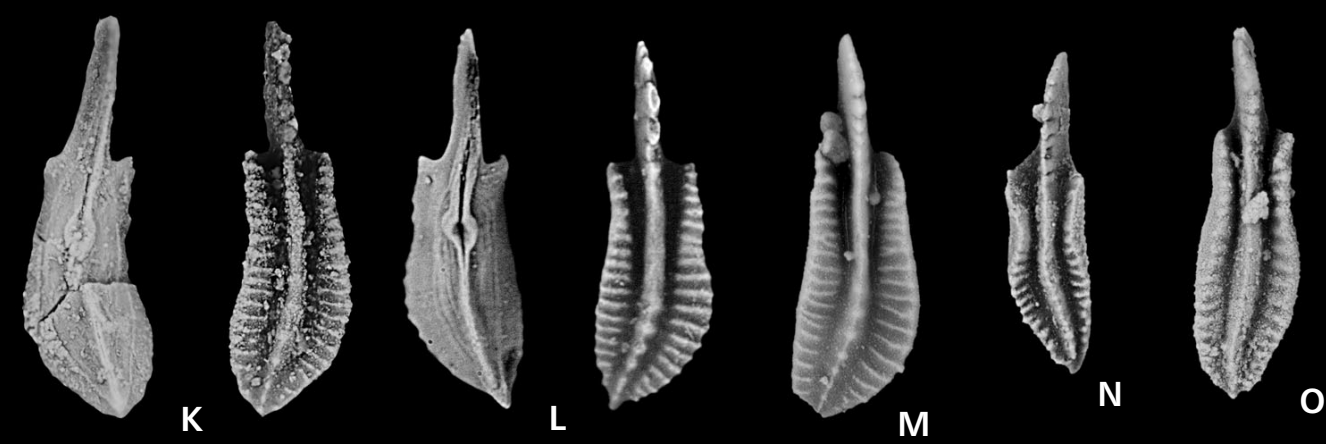

M

$\mathbf{0}$

Figure 6. A-I, K-L - Polygnathus costatus Klapper, 1971. • A-C, E-RCR 22 I, australis Zone, upper and lower views of UCR 10989 X/3, UCR 10989 I/20, UCR 10989 I/30 and upper view of UCR 10989 X/3). D - WC VI 2, costatus Zone, upper and lower views of UCR 10999 I/30. • F, G - Na Škrábku quarry, Prague Basin, $5 \mathrm{~m}$ above the base of the Choteč Limestone, costatus Zone, approximately $\times 40$, lower and upper views of SB3, upper and lower views of SB4. $\bullet \mathrm{H}-\mathrm{Na}$ Škrábku quarry, Prague Basin, $7 \mathrm{~m}$ above the base of the Choteč Limestone, costatus Zone, approximately $\times 40$, upper and lower views of SB5. $\bullet$ I - WC IIN 4, costatus Zone, lower and upper views of UCR 8700 I/40. $\bullet$ - WC VI 5C-1', costatus Zone, lower and upper views of UCR 11004. • L -New York, Seneca Member, Onondaga Limestone, loc. 5, sample 2, costatus Zone (Klapper 1971, pl. 2, figs 5-7), new illustrations of lower and upper views of holotype SUI 35096, approximately $\times 33$. $\bullet \mathrm{J}-$ Polygnathus cf. P. costatus; Antelope Range, section V, sample VG-25, Coils Creek Member (Johnson et al. 1996, table 2), costatus Zone, upper view of SUI 126794, approximately $\times 26 . \bullet$ M - Polygnathus patulus Klapper, 1971. Antelope Range, section V, sample VH-8, Coils Creek Member (Johnson et al. 1996, table 2), partitus Zone, upper view of SUI 126795, posterior tip broken, approximately $\times 26 . \bullet \mathrm{N}-\mathrm{O}-$ Polygnathus holynensis sp. nov., Antelope Range, section V, samples VH-32, SB-26, Coils Creek Member (Johnson et al. 1996, table 2), costatus Zone, upper views of paratypes SUI 126796, 126797, approximately $\times 26$. All magnifications approximately $\times 30$, unless mentioned otherwise.

1978 Polygnathus costatus costatus Klapper, 1971. Klapper, Ziegler \& Mashkova, pp. 109, 114, pl. 2, figs 10-12.

1986 Polygnathus sp. nov. - Schönlaub, p. 368, pl. 4, figs $18,19$.
1994 Polygnathus gilklapperi sp. nov.; Mawson \& Talent, pp. 46,47 , pl. 2, figs $5-8$ [figs $6,7=P$. costatus morphotype X].

2009 Polygnathus costatus costatus Klapper, 1971. - Berkyová, pp. 676, 678, figs 6I-K [see further synonymy]. 


\begin{tabular}{|c|c|c|c|c|c|}
\hline species & platform character & carina & transverse ridges & adcarinal areas & \\
\hline costatus & $\begin{array}{l}\text { narrow } p \text {.,inner } m \text {. straight } \\
\text { to slightly concave, then } \\
\text { expanded. Outer } m \text {. nearly } \\
\text { straight, then convex. } \\
\text { Maximal width of p. slightly } \\
\text { posterior of midlength }\end{array}$ & $\begin{array}{l}\text { continuous, or } \\
\text { ends shortly } \\
\text { anterior of tip. } \\
\text { Almost straight } \\
\text { or slightly curved }\end{array}$ & $\begin{array}{l}\text { closely, evenly } \\
\text { spaced. Interspaces } \\
\text { of the same size as } \\
\text { ridges or slightly wider }\end{array}$ & $\begin{array}{l}\text { narrow grooves } \\
\text { continouos to tip }\end{array}$ & \\
\hline partitus & $\begin{array}{l}\text { narrow } p ., \text { inner } m \text {. almost } \\
\text { straight to } 2 / 3 \text { of } p . \text {, then } \\
\text { angles in a straith margin to } \\
\text { tip. Outer m. almost straight } \\
\text { or slightly concave, } \\
\text { then convex taper to tip }\end{array}$ & $\begin{array}{l}\text { almost straight, } \\
\text { continuous, at } \\
\text { least in forms of } \\
\text { nodes }\end{array}$ & evenly spaced & $\begin{array}{l}\text { narrow, deep } \\
\text { grooves, shallow } \\
\text { posteriorly, } \\
\text { continuous to tip }\end{array}$ & \\
\hline patulus & $\begin{array}{l}\text { medium width, inner m. } \\
\text { concave then convex, } \\
\text { outer } m \text {. nearly straight } \\
\text { or slightly convex, then } \\
\text { convex to tip. Maximal } \\
\text { width of } p \text {. at midlength or in } \\
\text { posterior third }\end{array}$ & $\begin{array}{l}\text { commonly does not } \\
\text { reach posterior tip }\end{array}$ & $\begin{array}{l}\text { evenly } \\
\text { spaced, interspaces } \\
\text { wider then ridges }\end{array}$ & $\begin{array}{l}\text { moderately wide } \\
\text { deep anterior } \\
\text { troughs shallow } \\
\text { posteriorly }\end{array}$ & \\
\hline holynensis & $\begin{array}{l}\text { irregular shape of } p \text {. Inner } \\
\mathrm{m} \text {. nearly straight to } \\
\text { sinuous, outer } \mathrm{m} \text {. expanded } \\
\text { at midlength narrowing } \\
\text { posteriorly }\end{array}$ & $\begin{array}{l}\text { strong, slightly } \\
\text { curved, continuous } \\
\text { to tip or ends } \\
\text { slightly anteriorly } \\
\text { of tip. Recurved at } \\
\text { tip }\end{array}$ & $\begin{array}{l}\text { evenly and } \\
\text { closely spaced with } \\
\text { minimum of } \\
\text { intercalations and } \\
\text { branching }\end{array}$ & $\begin{array}{l}\text { similar to that of } \\
P . \text { costatus }\end{array}$ & \\
\hline cf. holynensis & $\begin{array}{l}\text { inner } \mathrm{m} \text {. almost straight, } \\
\text { outer } \mathrm{m} \text {. bulges at midlength }\end{array}$ & $\begin{array}{l}\text { similar to that of } \\
P . \text { holynensis }\end{array}$ & $\begin{array}{l}\text { irregular in size, spacing } \\
\text { and orientation with } \\
\text { intercalations, branching } \\
\text { and interruptions }\end{array}$ & $\begin{array}{l}\text { deep throughs pass } \\
\text { into troughs of } \\
\text { irregular width and } \\
\text { ragged margins }\end{array}$ & \\
\hline gilklapperi & $\begin{array}{l}\text { medium width of } \mathrm{p} \text {. Inner } \mathrm{m} \text {. } \\
\text { almost straight, outer } \mathrm{m} \text {. } \\
\text { biconvex }\end{array}$ & $\begin{array}{l}\text { variable: continuous } \\
\text { to tip in form of } \\
\text { nodes or ends in } \\
\text { posterior third of } p .\end{array}$ & $\begin{array}{l}\text { intercalation of ridges } \\
\text { possible }\end{array}$ & $\begin{array}{l}\text { deep troughs tapers } \\
\text { to midlength, shallow } \\
\text { and fade out in } \\
\text { posterior third }\end{array}$ & 8 \\
\hline salixensis & $\begin{array}{l}V \text { to } U \text { shape in cross section. } \\
\text { Medium width, margins } \\
\text { subparallel or slightly } \\
\text { diverging to } 3 / 4 \text { of } p \text {.,then } \\
\text { taper to tip }\end{array}$ & $\begin{array}{l}\text { continuous, almost } \\
\text { straight }\end{array}$ & $\begin{array}{l}\text { uniformly and closely } \\
\text { spaced, branching } \\
\text { and intercalations } \\
\text { common }\end{array}$ & $\begin{array}{l}\text { anterior troughs } \\
\text { pass into grooves } \\
\text { posteriorly }\end{array}$ & \\
\hline
\end{tabular}

Figure 7. Characteristic features of representatives of the costatus Group.

2010 Polygnathus costatus cf. partitus Klapper, Ziegler \& Mashkova 1978. - Machado et al., p. 445, pl. 2, fig. E [= P. costatus morphotype $\mathrm{X}]$.

Diagnosis. - A species of Polygnathus based on a Pa element with the following combination of characters: narrow platform with strong transverse ridges separated from carina by narrow, deep adcarinal grooves continuous to posterior end and that shallow somewhat posteriorly; ridges uniform and closely spaced; anterior platform margins nearly parallel; inner platform margin nearly straight to slightly concave, then slightly expanded posterior of 


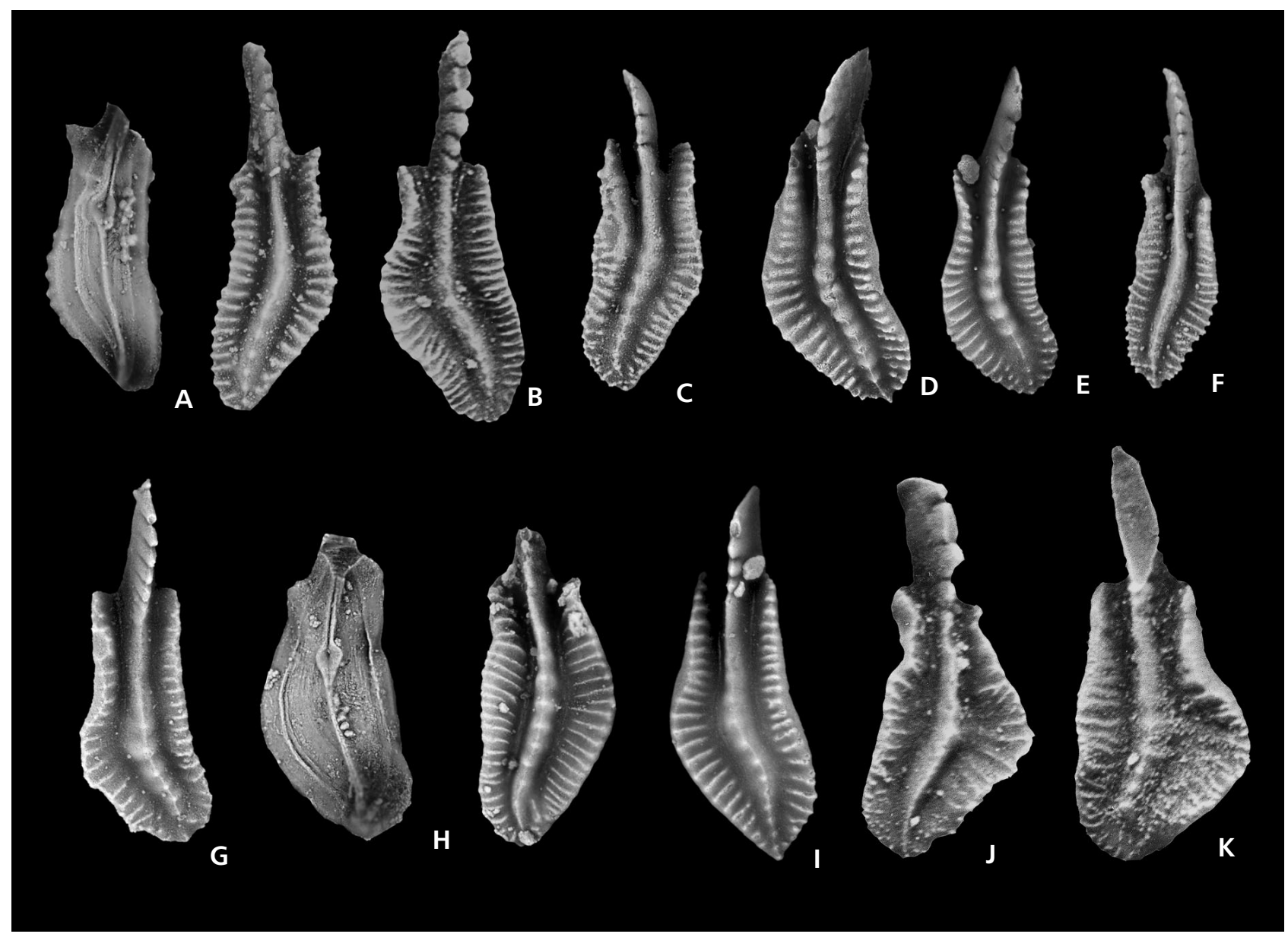

Figure 8. A-I-Polygnathus holynensis sp. nov. • A - RCR 19, australis Zone, lower and upper views of paratype UCR 10988 slide I/19 (free blade broken during manipulation of the specimen), approximately $\times 30$. $\bullet B-$ WC IIN $6 \mathrm{~A}+4$ ', costatus Zone, upper view of holotype UCR $8706 \mathrm{I} / 30$, approximately $\times 30 . \bullet$ C, F - Antelope Range, section V, sample VB-3, VH-32, Coils Creek Member (Johnson et al. 1996, table 2), costatus Zone, upper views of paratypes SUI 126798, 126799. • D-E, G, I - Hot Creek Range, Summit 8782, samples 11, 11, 8A, 11, Coils Creek Member (Johnson et al. 1986, fig. 7, table 8), costatus Zone, upper views of paratypes SUI 126800-126803. $\bullet \mathrm{H}-\mathrm{RCR} 31$, australis Zone, lower and upper views of paratype UCR $11022 \mathrm{I} / 15$, approximately $\times 30 \cdot \bullet \mathrm{J}, \mathrm{K}-$ Polygnathus $\mathrm{cf}$. P. holynensis. WC IIN 6A+4', costatus Zone, upper views of UCR 8706 I/30, UCR 8706 I/3, approximately $\times 30$. All magnifications approximately $\times 26$, unless mentioned otherwise.

the anterior third; outer margin in the anterior third nearly straight followed by a slightly expanded convex arc in the posterior two-thirds; widest part of platform slightly posterior of midlength; carina almost straight to slightly curved; posterior carina continuous to tip or ends shortly anterior of tip.

Description. - Pa element lower side: basal pit small with strong rims, located slightly anterior of platform midlength; anterior groove open, parallel-sided. Pa element upper side; anterior platform margins commonly meet free blade at almost a right angle; outer margin may have a weak sinus at the anterior third in a few specimens. Carina narrows to thinner nodes near the posterior end in some specimens and may extend shortly and distinctly beyond the posterior margins of the platform in some specimens. In exceptional specimens (Fig. 6I; also that of Schönlaub
1986, pl. 4, figs 18, 19) the adcarinal grooves extend in a circular arc around the posterior termination of the carina. Free blade with 5-6 compressed denticles. Unit is slightly arched.

Remarks. - Polygnathus patulus has a wider platform, adcarinal troughs instead of grooves, a generally shorter posterior carina, and more widely spaced transverse ridges, in contrast with that of $P$. costatus (slightly modified from Klapper 1971, p. 63). For a comparison of $P$. costatus with the closely similar $P$. holynensis, see under the latter. Specimens in Fig. 6F-H are regarded herein as a distinct morphotype of $P$. costatus. $P$. costatus morphotype $\mathrm{X}$ differs by having a conspicuous but small triangular tip posterior of the end of the carina, extending beyond the rest of the posterior platform margins and forming right angles with those margins. This feature is not to be confused with the 

tip of the carina, which extends in some specimens (e.g., Fig. 6B-E, L) beyond the rest of the posterior platform margins. We consider the specimens of Mawson \& Talent (1994, pl. 2, figs 6, 7; those on their pl. 2, figs 5, 8 are closely related) and that of Machado et al. (2010, pl. 2, fig. E) to belong to morphotype X.

A specimen termed here as Polygnathus cf. P. costatus (Fig. 6J) has adcarinal troughs instead of grooves and shorter and irregularly developed transverse ridges. For the summary of diagnostic features of the costatus Group see Fig. 7.

Stratigraphic range and occurrences. - Polygnathus costatus has an almost 'cosmopolitan' distribution (note the qualification of this term in Klapper \& Johnson 1980, p. 402, as Devonian conodonts were not then known in the large Malvinokaffric Realm and are not known there even as yet). The lowest occurrence of $P$. costatus in the Nevada sections was recorded at the base of the Denay Limestone at most of the sections studied (costatus Zone); the highest occurrence was recorded at about $150 \mathrm{~m}$ above the base of Denay Limestone at the RC 1 section, at the base of the kockelianus Zone, representing its highest known occurrence.

\section{Polygnathus holynensis sp. nov.}

Figures 6N, O, 8A-I

Holotype. - The specimen in Fig. 8B, UCR 8706 I/30.

Etymology. - The name is derived from the Holyně village near Prague, where the first specimen of this species was found.

Material. - 3 specimens from the Roberts Creek Ranch and Willow Creek, 3 specimens from the Prague Basin and more than 50 specimens from the northern Antelope Range and Hot Creek Range.

Diagnosis. - A species of Polygnathus based on Pa elements with the following combination of characters: narrow to medium, irregularly shaped platform with strong, evenly spaced transverse ridges separated from carina by narrow, relatively deep adcarinal grooves to narrow troughs that are continuous to posterior end but that may change to shallow, nearly equant grooves near tip; ridges uniformly spaced; inner platform margin nearly straight to sinuous, outer margin expanded at midlength narrowing posteriorly; carina straight to slightly curved inwardly; posterior carina continuous to tip or ends shortly anterior of tip and thins posteriorly and is recurved outwardly.

Description. - Pa element lower side: basal pit small with strong rims, located slightly anterior of platform midlength; anterior groove open, parallel-sided. Pa element upper side; anterior platform margins commonly meet free blade almost at a right angle; outer margin sinuous in most specimens; some specimens have irregularly spaced transverse ridges and some have nodes replacing the ridges posteriorly. There can be an extremely narrow shelf on the outer margin just anterior of midlength. Carina narrows to thinner nodes near the posterior end in some specimens. Free blade with 4-6 compressed denticles. Unit is slightly arched. Maximum width normally at mid-length of the platform.

Remarks. - Pa elements of Polygnathus holynensis sp. nov. have sinuous platform margins, carinas, and keels, as opposed to the closely similar species $P$. costatus and the platform is relatively longer. Although the outer platform margin may be expanded at midlength in some specimens of $P$. costatus, the outer platform does not narrow appreciably from that point to the posterior end.

Specimens termed here as Polygnathus cf. P. holynensis (Fig. 8J, K) have a much wider outer platform at midlength, with more intercalations between the transverse ridges, and more branching of the transverse ridges than in $P$. holynensis. The ridges are also less numerous and shorter.

Stratigraphic range and occurrences. - The new species was recorded in the Prague Basin at Na Škrábku quarry in the costatus Zone; at the Holyně section near Prague and the Hostim section near Beroun it occurs in the basal australis Zone (joint occurrence with $P$. pseudofoliatus). In the Roberts Mountains sections $P$. holynensis was found in the australis Zone, but it occurs in the costatus Zone in the northern Antelope Range section V and the Summit 8782 section in the northern Hot Creek Range.

\section{Polygnathus gilklapperi Mawson \& Talent, 1994} Figure 9E-J

1980 Polygnathus sp. nov. B Klapper, 1977. - Klapper \& Johnson, p. 454, pl. 4, figs 13, 14, 17, 18 [see synonymy; figs 13, $14=$ holotype selected by Mawson \& Talent 1994, p. 46].

1986 Polygnathus sp. nov. B of Klapper. - Klapper in Johnson et al., tables $1,8$.

[not] 1994 Polygnathus gilklapperi sp. nov.; Mawson \& Talent, pp. 46-47, pl. 2, figs 5-8 [Figs 5, $8=P$. costatus Klapper, 1971; figs 6, $7=P$. costatus morphotype $\mathrm{X}]$.

1996 Polygnathus sp. nov. B of Klapper. - Johnson, Klapper \& Elrick, table 2.

2002 Costapolygnathus gilklapperi (Mawson \& Talent, 1994). - Bardshev, Weddige \& Ziegler, p. 415, text-fig. 14, fig. 28 [reillustration of holotype].

Diagnosis. - A species of Polygnathus based on a Pa element with the following combination of characters: wide 
platform with strong transverse ridges in the anterior two thirds separated from carina by either adcarinal troughs or grooves (Fig. 9H, I), which terminate at the posterior third of the platform; ridges in posterior third may completely cross the platform, or be interrupted by nodes of the carina (Fig. 9E, G, H, I) or be partially replaced by lateral nodes (Fig. 9J) or some combination of these (Fig. 9F); transverse ridges are uniformly spaced, but some have much shorter ridges intercalated between those of normal length; anterior platform margins not parallel; inner platform margin nearly straight, outer platform margin expands into a convex curve posterior of midlength; widest part of platform and point of carina's curvature is at same point posterior of midlength; posterior carina either continuous to tip as a row of separate nodes or ends in the posterior third; basal pit located very slightly anterior of platform midlength.

Description. - Pa element lower side: moderate-sized basal pit with rims; anterior groove open, parallel-sided. Pa element upper side; anterior platform margins commonly meet free blade variably at a right to an acute angle; in a few specimens the outer margin may have a weak sinus at the anterior third (e.g., Fig. 9G, I) and also in the posterior third of a few (Fig. 9I, J). Carina narrows to thinner nodes near the posterior end in some specimens. Short free blade with 3-5 compressed denticles. Unit is slightly arched.

Remarks. - The pit of the closely related Polygnathus laticostatus Klapper \& Johnson, 1975 (Fig. 9D) has a distinctly larger pit with stronger rims than in the present species. The pit of Polygnathus patulus Klapper, 1971, is located closer to the anterior platform margin, about halfway between midlength and the anterior margin, as opposed to the Pa elements of $P$. gilklapperi.

In Polygnathus cooperi Klapper (1971, pl. 1, figs 17-22; Klapper et al. 1978, pl. 2, figs 21, 22, 29, 30) the anterior platform margins are parallel or close to parallel, the platform is narrower, and the transverse ridges in the anterior two-thirds of the platform are shorter than in P. gilklapperi.

As indicated in the synonymy list, Mawson \& Talent (1994) designated the holotype of $P$. gilklapperi from a sample from the Summit 8782 section in the northern Hot Creek Range, central Nevada, illustrated by Klapper \& Johnson (1980). However, the Australian specimens Mawson \& Talent (1994, pl. 2, figs 5-8) attributed to their new species belong instead to $P$. costatus, based on differences in the platform outline, position of the pit, and distribution of ornament on the upper surface. In having a conspicuous but small triangular tip that extends posterior of the rest of the platform margins, their specimens in pl. 2, figs 6, 7 indicate identification with $P$. costatus morphotype $\mathrm{X}$.
Stratigraphic range and occurrences. - Polygnathus gilklapperi occurs only in Nevada as far as is presently known. It does not occur in our Roberts Mountains collections, because the costatus Zone in the lower Denay Limestone lies unconformably on the serotinus Zone of the upper Coils Creek Member of the McColley Canyon Formation, where only a few samples were taken. The species occurs in the serotinus and partitus zones in the Summit 8782 section in the northern Hot Creek Range (Johnson et al. 1986, table 8) and in the same two zones in section V in the northern Antelope Range (Johnson et al. 1996, table 2; see revised zonal identifications of the partitus Zone for samples VH 6-8 in Elrick et al. 2009, p. 171).

\section{Polygnathus salixensis sp. nov.} Figure 10A-B, D-K

Holotype. - The specimen in Fig. 10G, UCR 11000 II/5.

Etymology. - Salix is Latin for willow; the species is named for Willow Creek, one of the main localities for Lower Eifelian conodonts in the Roberts Mountains, central Nevada.

Material. - 86 specimens.

Diagnosis. - A species of Polygnathus based on a Pa element with the following combination of characters: wide, subquadrate to lenticular platform with wide transverse ridges separated from the carina by narrow, deep adcarinal grooves anteriorly and posteriorly that are continuous to the posterior end; transverse ridges uniformly and closely spaced, but some are branched and some have much shorter ridges intercalated between those of normal length; open ' $v$ ' to ' $u$ ' - shaped platform cross section; platform margins roughly parallel until the posterior third where they converge to the pointed tip; carina continuous to posterior tip, almost straight to slightly curved.

Description. - Pa element lower side: basal pit small with rims, located slightly anterior of platform midlength; anterior grooves open. Pa element upper side; anterior platform margins meet free blade at almost a right angle; outer margin commonly a convex curve but a sinus may be developed in the posterior third, inner margin with a sinus at the anterior third followed by a convex curve to the tip. Depth of cross section variable from shallow to deep. Carina thins in the posterior third or fourth. Free blade short with about 4-5 compressed denticles. Unit is slightly arched.

Remarks. - Pa elements of the similar species, $P$. costatus, have a narrower anterior platform and the range of 


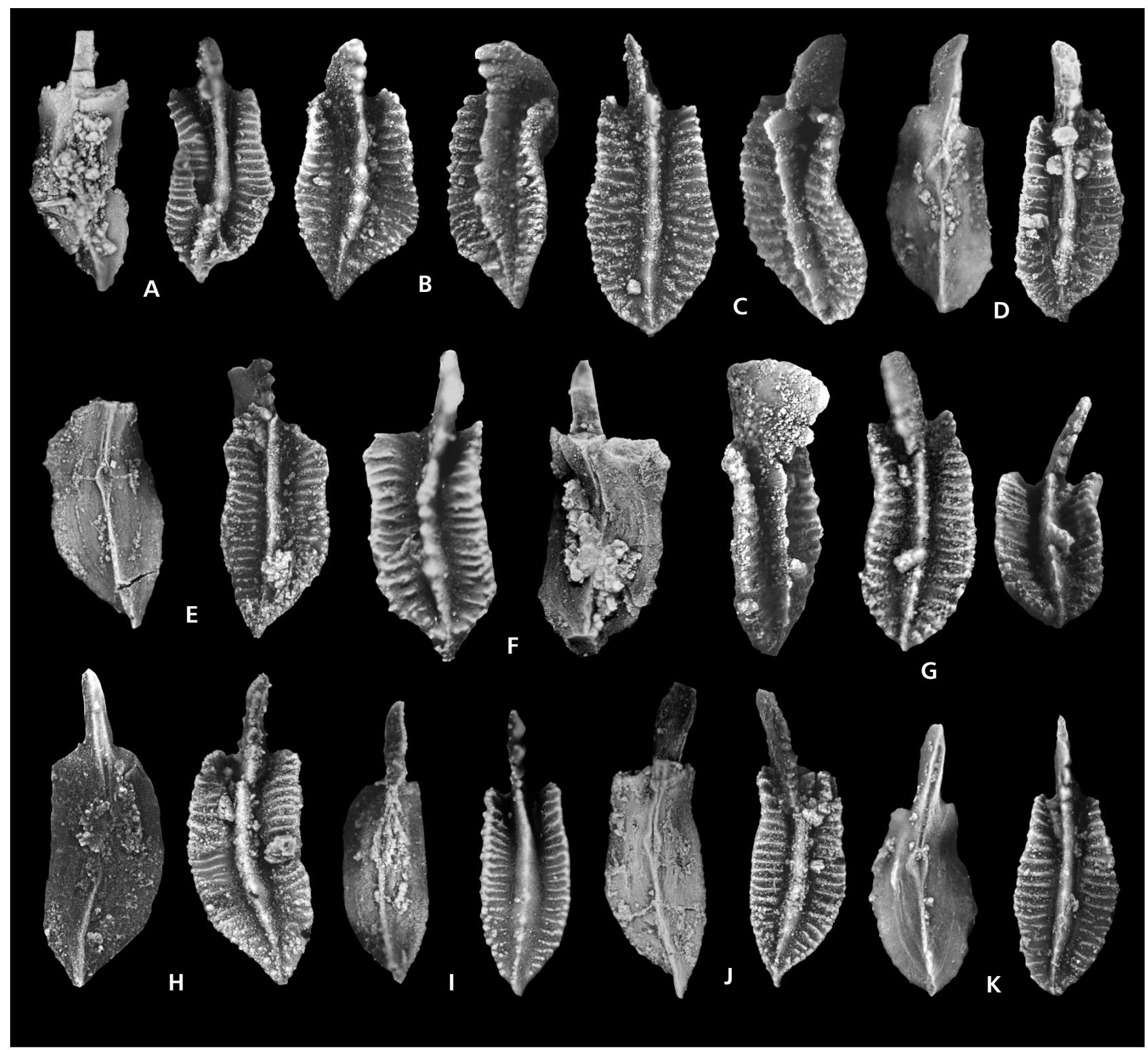

Figure 10. A-B, D-K - Polygnathus salixensis sp. nov. • A - RCR 17, australis Zone, lower and upper views of paratype UCR 10987 V/23). - B, D, G-H - WC VI 4A, costatus Zone, upper and oblique-lateral views of paratype UCR 11000 II/2, lower and upper views of paratype UCR 11000 I/15, oblique-lateral, upper, and posterior views of holotype UCR 11000 II/5, lower and upper views of paratype UCR 11000 I/16. - E, J - WC VI 5C-1', costatus Zone, lower and upper views of paratype UCR 11004 II/43 (free blade broken during manipulation of the specimen); lower and upper views of paratype UCR 11004 II/15. - F - WC IIN4, costatus Zone, upper and lower views of paratype UCR 8700 I/41. - I - RCR 22, australis Zone, lower and upper views of paratype UCR $10989 \mathrm{X} / 1$. K - WC VI 2, costatus Zone, lower and upper views of paratype UCR 10999 II/31. • C - Polygnathus cf. salixensis, WC VI 4A, costatus Zone, upper and oblique-lateral views of UCR 11000 II/3. All magnifications approximately $\times 30$.

variation does not include a ' $\mathrm{v}$ ' shaped platform cross section, as opposed to the new species. In $P$. salixensis sp. nov. the transverse ridges are wider because the platform is wider than in $P$. costatus, which lacks both the branched and intercalated ridges of the new species.

The form we identify as $P$. cf. P. salixensis (Fig. 10C) has much shallower posterior adcarinal grooves, thus flat- tening the posterior platform in contrast with the new species. The specimen in Fig. 10F is an end member of the new species in terms of the platform outline and the deeper adcarinal troughs and grooves.

Stratigraphic range and occurrences. - The new species has been recorded in the costatus and australis zones in the Roberts Mountains. 


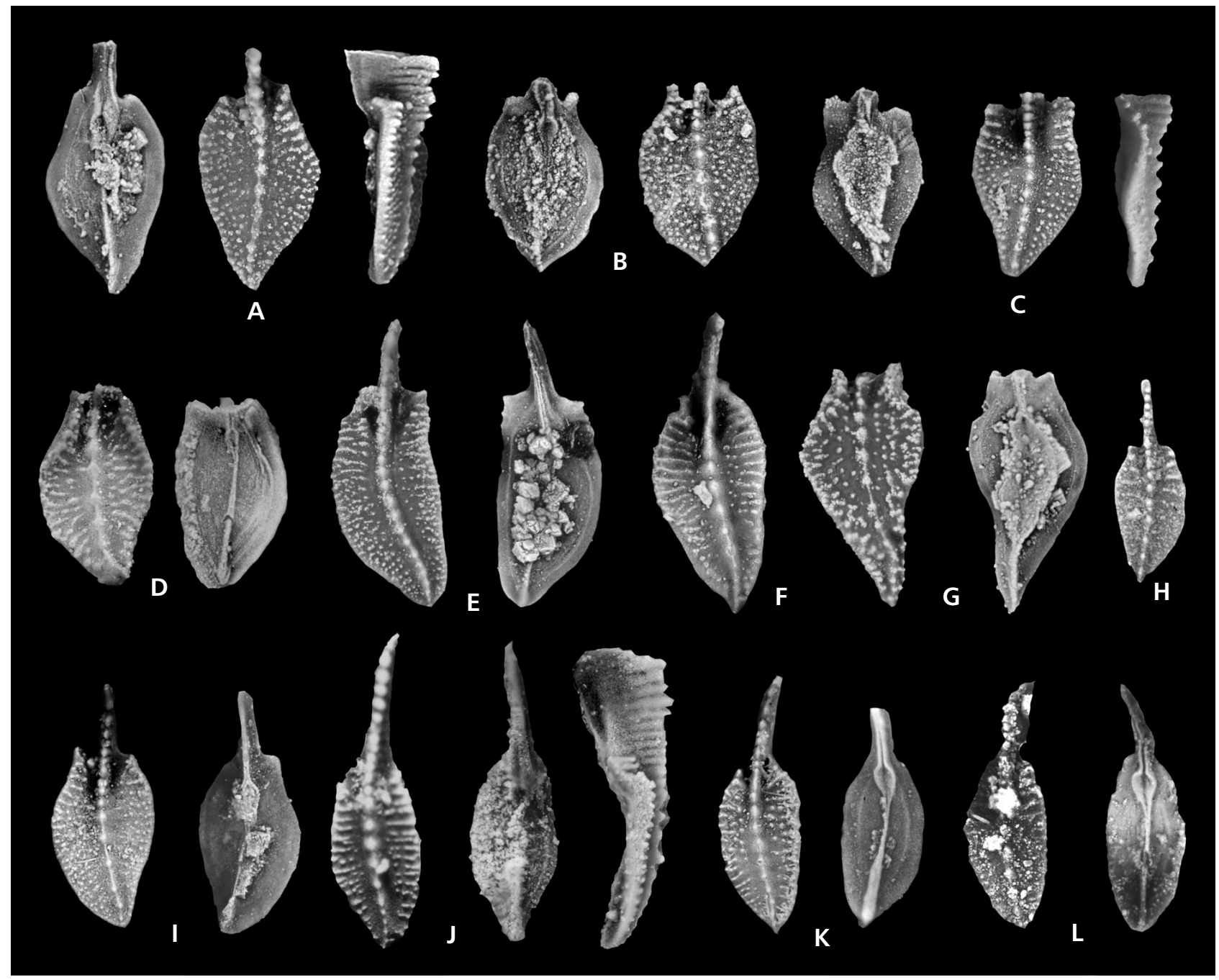

Figure 11. A-D, G, I-Polygnathus abbessensis Savage, 2011. • A-C, G - WC IIN 8+14 (UCR 8714), australis Zone, lower, upper and lateral views of UCR $8714 \mathrm{I} / 1$, lower and upper views of UCR $8714 \mathrm{II} / 45$, lower, upper and lateral views of UCR $8714 \mathrm{II} / 23$, upper and lower views of UCR 8714I/3. • D - WC IIN 8, australis Zone, upper and lower views of UCR 8714 III/1. • I - WC VI 17, australis Zone, upper and lower views of UCR $11045 \mathrm{I} / 13$. $・ \mathrm{E}-\mathrm{F}, \mathrm{H}, \mathrm{J}-\mathrm{L}-$ Polygnathus benderi Weddige, 1977. • E-F, H - WC IIN 8+14 (UCR 8714), australis Zone, upper and lower views of UCR $8714 \mathrm{I} / 5$, upper views of UCR $6714 \mathrm{II} / 46$, UCR $8714 \mathrm{II} / 47$. $・$ J - WC IIN 7, australis Zone, upper, lower and lateral views of UCR 8712 II/1. K, L - RCR 45, kockelianus Zone, upper and lower views of UCR 11032 VIII/1, UCR 11032 V/1. All magnifications approximately $\times 30$.

Polygnathus benderi Weddige, 1977

Figure 11E, F, H, J-L

1977 Polygnathus benderi sp. nov. - Weddige, p. 308, pl. 3, figs 59-61 [fig. 59 = holotype].

1979 Polygnathus benderi Weddige, 1977. - Lane \& Ormiston, p. 88, pl. 9, fig. 8 .

1983 Polygnathus benderi Weddige, 1977. - Wang \& Ziegler, p. 100, pl. 5, fig. 21.

(not) 1992 Polygnathus benderi Weddige, 1977. - Bardashev, p. 64, pl. 2, fig. 27.

1994 Polygnathus benderi Weddige. - Mawson \& Talent, p. 54, pl. 2, fig. 14 .
Diagnosis. - A species of Polygnathus based on a Pa element with the following combination of characters: elliptically shaped platform covered mostly or entirely with nodes; adcarinal grooves absent to weakly developed; platform widest at midlength; slightly curved carina continuous to posterior tip and slightly recurved outwardly near posterior tip.

Description. - Pa element lower side: basal pit small with rims, located slightly anterior of platform midlength in adult specimens, but closer to anterior end in juveniles including the holotype; anterior groove thin, parallel-sided. Pa element upper side: anterior platform 
margins commonly meet free blade at an acute angle; short transverse ridges or aligned nodes may be developed anteriorly and/or posteriorly in the Nevada specimens but not in the types. Margins are upturned anteriorly in the holotype, forming short anterior troughs. Such troughs are present in some of the Nevada specimens (e.g., Fig. 11E, F), but are absent in others. The weakly developed adcarinal grooves posterior of the short troughs are narrow and very shallow. Carina may be replaced by fine nodes near the posterior end in a few specimens. Long free blade with about ten compressed denticles. Unit is slightly arched.

Remarks. - Pa elements of P. abbessensis Savage, 2011, have a shorter and wider platform with the basal pit very close to the anterior end, in contrast with $P$. benderi in which the pit is closer to midlength in adult specimens. The outer anterior margin in most specimens of $P$. abbessensis is constricted but not in the holotype nor in $P$. benderi.

The specimen of Bardashev (1992, pl. 2, fig. 27) differs from $P$. benderi in its platform outline and the presence of transverse ridges.

Stratigraphic range and occurrences. - See Klapper \& Johnson (1980) and references therein. Polygnathus benderi occurs in the australis Zone in the Roberts Mountains.

\section{Polygnathus abbessensis Savage, 2011}

Figure 11A-D, G, I

1977 Polygnathus sp. A; Savage, p. 1350, pl. 1, figs 13-18. 1977 Polygnathus sp. C; Savage, p. 1354, pl. 2, figs 5-8.

1980 Polygnathus sp. A Savage. - Klapper \& Johnson, p. 454, pl. 4, fig. 10.

1995 Polygnathus borealis sp. nov.; Savage, p. 550, figs 6.10-6.12, fig. 8.11 [= holotype, reillustration of Savage, 1977, pl. 1, fig. 13; not fig. 8.10].

2011 Polygnathus abbessensis n. name; Savage, p. 810.

Diagnosis. - A species of Polygnathus based on a Pa element with the following combination of characters: ovalshaped but posteriorly pointed platform covered mostly with nodes and some transversely aligned nodes; very short adcarinal troughs present anteriorly; platform widest at midlength and flat posterior of the troughs without adcarinal grooves in mature specimens; carina almost straight to gently curved and continuous to posterior tip.

Description. - Pa element lower side: basal pit small with rims, located very close to the anterior margin of the platform; anterior groove thin, parallel-sided. Pa element upper side: anterior platform margins meet free blade at an obtuse angle directed diagonally to the posterior; incipient rostral ridges, built up with nodes, border the short anterior troughs. Short free blade with about five compressed denticles. Unit is slightly arched.

Remarks. - For a comparison with the closely similar $P$. benderi, see under the latter. We exclude from $P$. abbessensis a specimen illustrated by Savage (1995, fig. 8.10) because of the different platform outline and the anterior terminations of the platform margins, which are at a right angle. Also, the adcarinal troughs extend farther posteriorly in this specimen.

We interpret the specimen termed Polygnathus sp. C by Savage (1977) as an early ontogenetic stage of $P$. $a b$ bessensis; it is almost identical to the specimen illustrated by Klapper \& Johnson (1980), which we also include in P. abbessensis.

Polygnathus borealis Savage, 1995 is a junior homonym of $P$. borealis Nassedkina \& Plotnikova, 1979. Savage (2011) proposed $P$. abbessensis as a replacement name.

Stratigraphic range and occurrences. - Savage (1977) reported this species from the australis Zone in Alaska. Klapper \& Johnson (1980, table 8) reported this species from the australis and kockelianus zones, northern Antelope Range, and Klapper in Johnson et al. (1996, table 2) recorded it in the australis and basal kockelianus zones in Antelope section V. It occurs in the australis Zone in the Roberts Mountains.

\section{Polygnathus parawebbi Chatterton, 1974} Figure 12A-I

1974 Polygnathus parawebbi sp. nov.; Chatterton, pp. 1473, 1474, 1476, 1478, pl. 1, figs 12, 15-19, 25-27 [fig. $18=$ holotype $=$ alpha morph]; pl. 2, figs $1-9$, pl. 3, figs $15-17$.

Figure 12. A-I -Polygnathus parawebbi Chatterton, 1974. • A - WC IIN 10A-2, australis Zone, upper and lower views of UCR 8724/1. • B, C - WCIIN 8+14 (UCR 8714), australis Zone, upper and lower views of UCR 8714 II/8 and lower and upper views of UCR 8714 II/9. • D, I - WC VI 17, australis Zone, lower and upper views of UCR 11045 I/34 and UCR 8671 I/15. E, F - RCR 14, australis Zone, lower and upper views of UCR 11045 I/21 and UCR 10986/2. • G, H - WC II 937, UCR 8671, costatus Zone, upper and lower views of UCR 8671 I/4 and lower and upper views of UCR 8671 I/9. - J, K - Polygnathus bagialensis Savage, 2011. J - RCR 14, australis Zone, lower, upper, and lateral views of UCR 10986 I/40. K - WC IIN 8+14, australis Zone, upper and lateral views of UCR 8714 II/5. All magnifications approximately $\times 30$. 
1977b Polygnathus parawebbi Chatterton, 1974. - Klapper in Ziegler, pp. 477-479, Polygnathus - pl. 11, figs 8-10 [fig. $10=$ reillustration of holotype; synonymy].

1979 Polygnathus parawebbi Chatterton. - Chatterton, pp. 195-197, pl. 2, figs 1-17, 19-28 [figs 1-7, 19-28= alpha morph, figs $8-17=$ beta morph]; pl. 4, figs 4 7 [= gamma morph]; pl. 9, figs 9-11, 14-16 [figs 9-11 = alpha morph, figs 14-16 = beta morph].

1980 Polygnathus parawebbi Chatterton. - Klapper in Johnson et al., pp. 102, 103, pl. 4, figs 18-21 [figs 18, $19=$ alpha morph, figs 20, 21 = beta morph].

1983 Polygnathus parawebbi Chatterton, 1974. - Klapper \& Barrick, pp. 1239, 1240, figs 12Q, W, X, AA [beta morph].

1998 Polygnathus parawebbi Chatterton. - Uyeno, pp. 164, pl. 11 , figs $1-3,15,16,19$; pl. 12 , figs $6,10-12$, 24, 27; pl. 14, figs 15-18.

Diagnosis. - A species of Polygnathus based on a Pa element with the following combination of characters: platform narrow anteriorly and curved inward very strongly in posterior third; with strong transverse ridges separated from carina by relatively deep adcarinal grooves either continuous to posterior end or terminating anterior of the tongue; ridges more closely spaced anteriorly, most widely spaced at point of maximum curvature on the outer side; transverse ridges on anterior outer margin area tend to disappear in some specimens of both morphs; anterior platform margins nearly parallel, inner platform margin a shallow concave curve; outer anterior margin either straight followed by a sharp angular deflection inwardly to posterior tip (alpha morph) or it is slightly concave anteriorly then changes to a convex arc to the tip (beta morph); posterior carina either more or less continuous to tip (alpha) or commonly terminates anterior of the transverse ridges that cross the tongue (beta).

Description. - Pa element lower side: basal pit small with strong rims, located slightly anterior of platform midlength; anterior groove open, parallel-sided; keel strongly curved inwardly beginning slightly posterior of pit. Pa element upper side: anterior platform margins commonly meet free blade at almost a right angle; outer margin of two types as given in the diagnosis. In the alpha morph the posterior carina may be either continuous to the tip or replaced by a few separate nodes or a very narrow ridge. The beta morph commonly has transverse ridges that cross the tongue, but some specimens lack these ridges and instead have the carina continuous to the posterior tip (Chatterton 1979, pl. 9, fig. 14; Klapper \& Barrick 1983, figs 12Q, W, X, AA). The two morphs, however, are distinguished mainly by the platform outline. Long free blade with 5-11 compressed denticles. Element is arched.

Remarks. - Two morphs of the Pa element of Polygnathus parawebbi recognized by Chatterton (1979) are also pre- sent in the Nevada collections (Fig. 12G-I = alpha morph, Fig. $12 \mathrm{~A}-\mathrm{F}=$ beta morph). They differ in the configuration of the outer platform outline, as given in the diagnosis. Furthermore, in the alpha morph the outer posterior margin adjacent to the beginning of the tongue is slightly higher than the opposite inner margin, whereas in the beta morph they are at the same height. In contrast, in P. linguiformis Hinde, 1879 s.s. (= gamma morph of authors) the outer posterior margin adjacent to the beginning of the tongue is much higher forming a flange, as opposed to the alpha morph of P. parawebbi. Chatterton $(1974,1979)$ has reconstructed the multielement apparatus of Polygnathus parawebbi.

Stratigraphic range and occurrences. - Polygnathus parawebbi has an almost "cosmopolitan" distribution reported from the australis to the varcus zones (Belka et al. 1997, Mawson \& Talent 1989): North America (e.g., Klapper \& Barrick 1983, Klapper \& Johnson 1980 and references therein, Uyeno 1998); North Africa (Belka et al. 1997); Europe (Narkiewicz \& Bultynck 2007), central Asia (e.g., Bardashev 1992), central Russian Platform (Kononova \& Kim 2005), Australia (e.g., Mawson \& Talent 1989). In the Roberts Mountains this species occurs in the australis and kockelianus zones.

\section{Polygnathus bagialensis Savage, 2011}

Figure 12J, K

1971 Polygnathus trigonicus Bischoff \& Ziegler, 1957. Klapper, p. 66, pl. 3, figs 9, 10 [not figs 7, 8, 11, $12=$ P. trigonicus]

1977 Polygnathus trigonicus Bischoff \& Ziegler, 1957. Savage, p. 1353, pl. 1, figs 1-12.

1992 Polygnathus trigonicus Bischoff \& Ziegler, 1957. Bardashev, p. 64, pl. 2, figs 37-40.

1995 Polygnathus praetrigonicus sp. nov.; Savage, p. 550, figs 8.8, 8.9 [reillustration of Savage 1977, pl. 1, figs 5, 9; fig. $8.8=$ holotype].

2011 Polygnathus bagialensis n. name; Savage, p. 810.

Diagnosis. - A species of Polygnathus based on a Pa element with the following combination of characters: wide triangular platform with closely and uniformly spaced strong transverse ridges, separated at the anterior end from carina by short, deep adcarinal troughs that abruptly change to narrow adcarinal grooves shallowing posteriorly; the grooves reach or almost reach the posterior tip; transverse ridges may be replaced posteriorly by nodes; pit closer to midlength than anterior platform margin, unit strongly arched.

Description. - Pa element lower side: basal pit small with strong rims; anterior groove wide and deep, parallel-sided. 

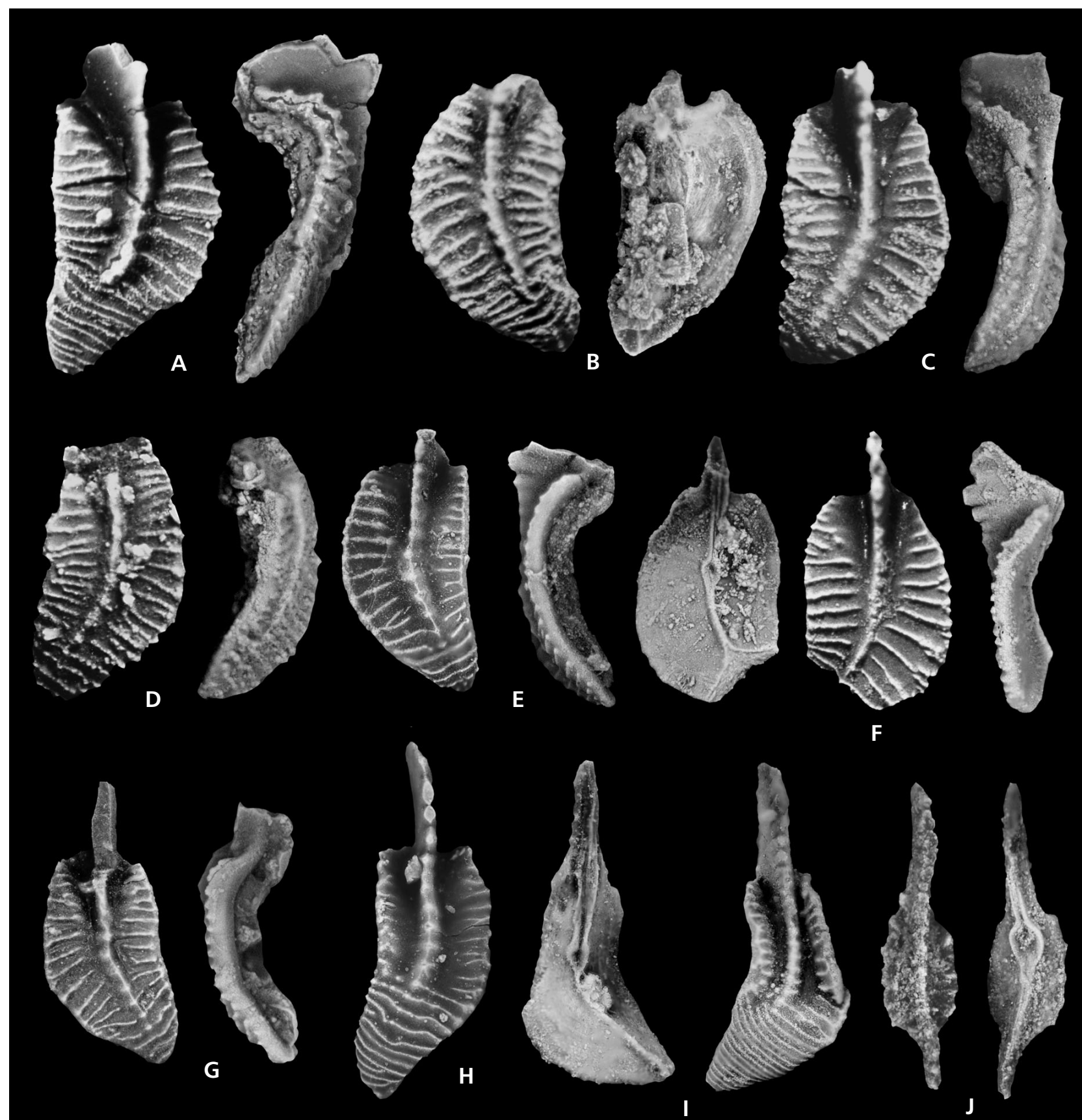

$\mathbf{F}$
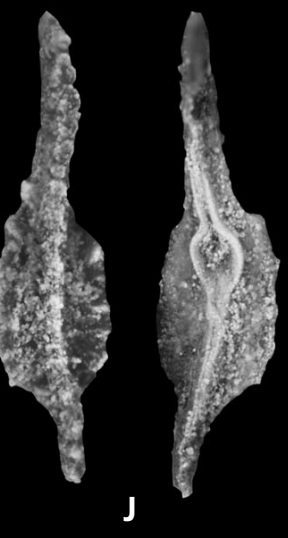

Figure 13. A-G-Polygnathus robertsensis $\mathrm{sp}$. nov. $\bullet \mathrm{A}, \mathrm{E}-\mathrm{G}-\mathrm{RCR} 22$, australis Zone, upper and lateral views of holotype UCR 10989/1, upper and lateral views of paratype UCR $10989 \mathrm{VI} / 30$, lower, upper, and lateral views of paratype UCR $10989 \mathrm{II} / 18$, upper and lateral views of paratype UCR UCR 10989 II/19. • B-D - WC IIN5, costatus Zone, upper and lower views of paratype UCR 10989 II/19, upper and lateral views of paratype UCR 8702 IV/1 and upper and lateral views of paratype UCR 8702 IV/2. • H, I -Polygnathus bultyncki Weddige, 1977. H - WC VI 32-3 +6", costatus Zone, upper view of UCR 10991/1. I - WC IIN 6D, costatus Zone, lower and upper views of UCR 8710 I/30. • -Polygnathus angusticostatus Wittekindt, 1966, WC VI 10, costatus Zone, upper and lower views of UCR $11040 \mathrm{I} / 29$. All magnifications approximately $\times 30$.

Pa element upper side: short anterior adcarinal troughs together form a v-shape and may be bordered on one side by a diagonal row of nodes; transverse ridges terminate at edge of both the adcarinal troughs and the adcarinal grooves; anterior platform margins meet free blade variably at al- most a right to an acute angle. High, short free blade has 6-7 compressed denticles.

Remarks. - Pa elements of Polygnathus bagialensis Savage, 2011 are closely comparable to those of $P$. trigonicus but in 
that species the pit is situated at the anterior platform margin, the anterior adcarinal troughs are bordered by diagonal rows of nodes, which converge posteriorly, and the platform is less highly arched. Pa elements of Polygnathus praetrigonicus Bardashev 1992 (= P. aff. P. trigonicus Klapper, 1971 and later authors) have more widely spaced transverse ridges, the adcarinal troughs extend farther posteriorly, and the anterior platform margins characteristically meet the free blade at a right angle (Klapper \& Vodrážková in prep.).

Polygnathus bagialensis Savage, 2011 occurs in the costatus and australis zones in Nevada and was originally described from the australis Zone in southeastern Alaska (Savage 1977, 1995). P. praetrigonicus Bardashev, 1992 occurs in the partitus and costatus zones in the northern Antelope Range, Nevada (Klapper \& Vodrážková in prep.), the costatus Zone in New York (Klapper 1971), and the basal costatus Zone in the Prague Basin (Berkyová 2009, Klapper et al. 1978). Bardashev (1992) gives the range as partitus and costatus zones in Central Asia.

Polygnathus praetrigonicus Savage, 1995 is a junior homonym of Polygnathus praetrigonicus Bardashev, 1992 (= $P$. aff. $P$. trigonicus Klapper, 1971 and later authors). Savage (2011) proposed $P$. bagialensis as a replacement name.

Stratigraphic range and occurrences. - Specimens assigned herein to Polygnathus bagialensis were recorded in the australis Zone in southern Alaska (Savage 1977) and the costatus Zone in New York (Klapper 1971). The occurrence reported by Bardashev (1992) from central Asia is from the australis Zone. It occurs in the australis Zone in the Roberts Mountains.

\section{Polygnathus robertsensis sp. nov.}

Figure 13A-G

1980 Polygnathus linguiformis linguiformis Hinde theta morphotype; Klapper in Johnson, Klapper \& Trojan, pp. 102, 114, pl. 4, figs 35,36 .

Holotype. - The specimen in Fig. 13A, UCR 10989/1.

Etymology. - The species name derives from the Roberts Mountains.

Material. - 11 specimens.

Diagnosis. - A species of Polygnathus based on a Pa element with the following combination of characters: wide platform with strong transverse ridges separated at the anterior end from carina by $\mathrm{v}$-shaped adcarinal troughs that abruptly shallow to narrow adcarinal grooves at midplatform, terminating before the tongue; complete transverse ridges on tongue more closely spaced than those anteriorly; some transverse ridges are branched and some have much shorter ridges intercalated between those of normal length; inner platform margin nearly straight, outer margin a convex arc and nearly parallel to carina; platform widest at midlength; posterior carina incomplete but penetrates the tongue to a variable degree.

Description. - Pa element lower side: basal pit small with strong rims, slightly anterior of center of platform; anterior groove open, parallel-sided. Pa element upper side: anterior transverse ridges extend from margins to adcarinal troughs; at mid-platform adcarinal grooves are shallow and well defined; anterior platform margins commonly meet free blade at almost a right angle. High, short free blade has 3-4 compressed denticles. Unit is strongly arched.

Remarks. - Pa elements of Polygnathus robertsensis sp. nov. differ from those of $P$. damelei sp. nov. in lacking the conspicuous sinus in the outer posterior margin and in having a shorter free blade. Polygnathus damelei has wide, deep adcarinal troughs throughout the platform anterior of the tongue, as opposed to the abrupt narrowing of the troughs into shallow adcarinal grooves at mid-platform in P. robertsensis. Also, in $P$. damelei the anterior platform margins are more or less parallel as opposed to $P$. robertsensis. They are similar, however, in the disposition and spacing of the transverse ridges.

We have observed the basal pit in only a few specimens of the new species because the lower side of other specimens has the pit covered either by basal plate material or quartz grains.

Stratigraphic range and occurrences. - Polygnathus robertsensis is known only from Nevada. It was recorded by Klapper in Johnson et al. (1980) in the northern Antelope Range from the costatus Zone and by Klapper in Johnson et al. (1996, table 2) from the same zone in Antelope section V. It occurs in the costatus and basal australis zones in the Roberts Mountains.

\section{Polygnathus damelei sp. nov.}

Figure $14 \mathrm{~A}-\mathrm{F}$

1986 Polygnathus zieglerianus Weddige. - Bultynck, p. 282 , pl. 7, fig. 11 [not figs 10, 15, 16 = P. zieglerianus Weddige, 1977].

Holotype. - The specimen in Fig. 14E, UCR 11004 I/16.

Etymology. - The species is named for Roy D. Damele, who was the proprietor of the Willow Creek Ranch during the time that collections of the faunas from the Denay Limestone were being made by M.A. Murphy. Mr. Damele furnished accommodations at the ranch, logistical support in the field, maintenance and repair of equipment essential to our work. 


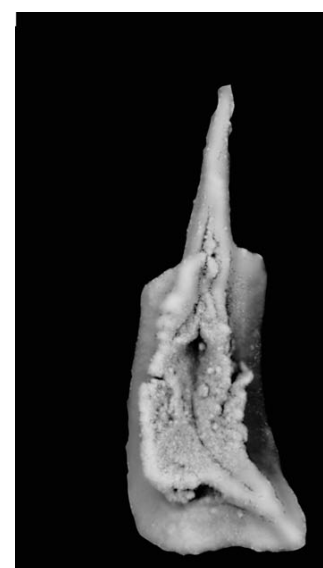

A
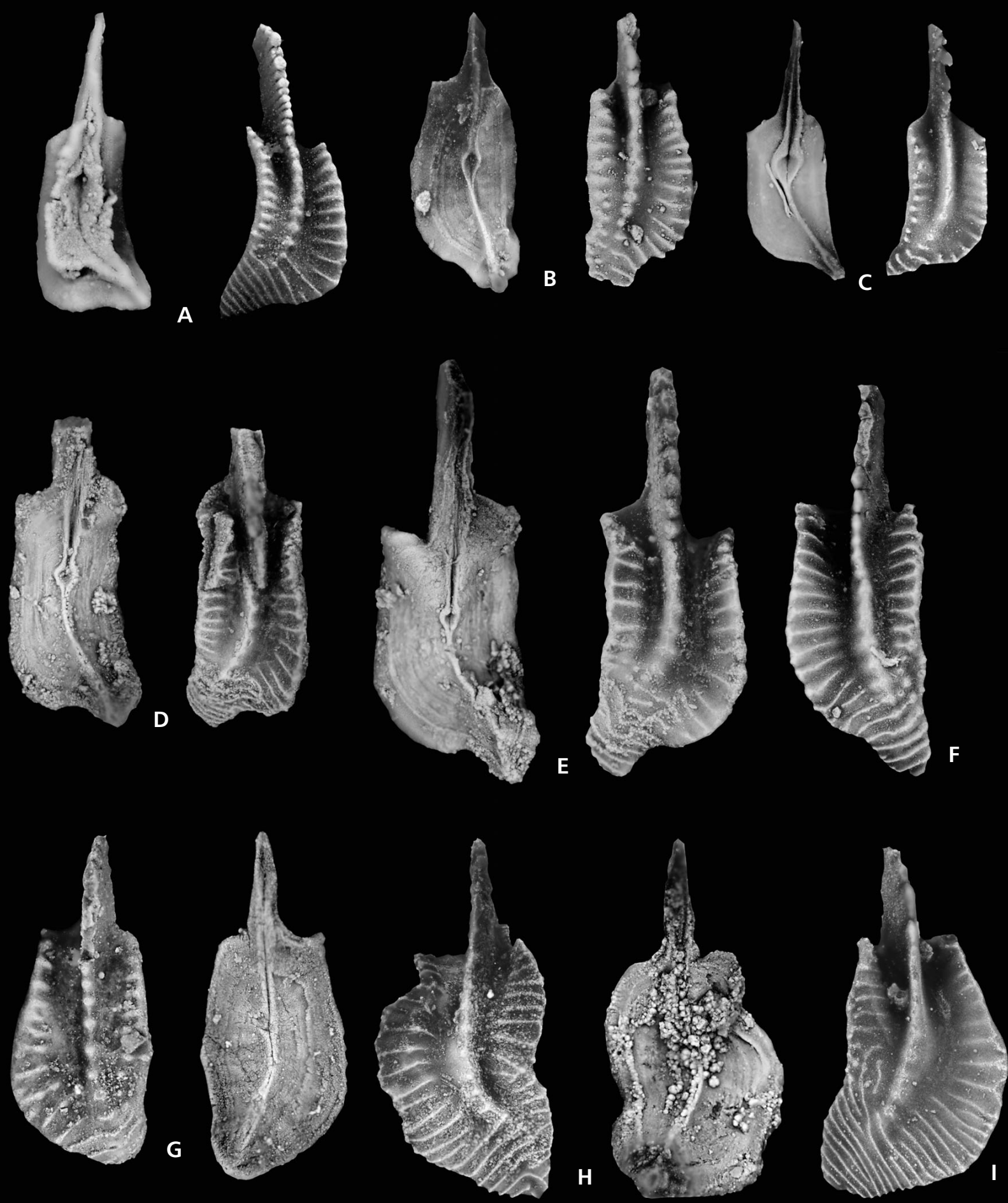

Figure 14. A-F - Polygnathus damelei sp. nov. • A - RCR 14, australis Zone, lower and upper views of paratype UCR 10986 IV/1. B - WC VI, H32-3+6", costatus Zone, lower and upper views of paratype UCR 10992/2. • C - RCR 23, australis Zone, lower and upper views of paratype UCR 11051/1). D, E - WC VI 5C-1'(UCR 11004), costatus Zone, lower and upper views of paratype UCR 11004 I/28 and holotype UCR 11004 I/16. -F - WC VI 2, costatus Zone, upper view of paratype UCR 10999/1. • G-H -Polygnathus aff. P. pinguis Weddige, 1977. G, I- WC VI 4A (UCR 11001), costatus Zone, upper and lower views of UCR 11001 IV/40, upper view of UCR 11001 IV/37). H - WC VI 5C-1', costatus Zone, upper and lower view of UCR 11004 I/18. All magnifications approximately $\times 30$. 
Material. - 74 specimens.

Diagnosis. - A species of Polygnathus based on Pa elements with the following combination of characters: wide platform with strong, equally spaced transverse ridges separated from carina on the anterior platform by wide, deep adcarinal troughs that terminate before the tongue; strong transverse ridges on tongue are generally more closely spaced than those anteriorly; anterior platform margins almost parallel; posterior carina incomplete but penetrates the tongue to a slight degree; a conspicuous sinus is present in outer posterior margin; outer posterior margin at about same height as opposite inner margin.

Description. - Pa element lower side: medium to smallsized basal pit slightly anterior of platform center in adult specimens, closer to the anterior in juvenile specimens, migrating posteriorly and decreasing in size with growth; anterior groove open, parallel-sided, deep. $\mathrm{Pa}$ element upper side: transverse ridges extend from anterior margins to adcarinal troughs which are deep and well defined anterior of the tongue; depth and width variable on mid-platform, anterior platform margins meet free blade at about a right angle. Free blade, about a third of the total length, has 6-7 compressed denticles. Unit is slightly arched.

Remarks. - In the parallel-sided anterior platform margins and the conspicuous sinus in the outer platform margin, the Pa element of $P$. damelei sp. nov. is distinguished from both $P$. pinguis Weddige, 1977, and the form we have identified here as $P$. aff. $P$. pinguis. Polygnathus zieglerianus Weddige (1977, pl. 6, figs 100, 101) lacks the conspicuous sinus in the outer posterior margin and the transverse ridges on the tongue are not as well developed as compared with P. damelei.

The platform outline of $P$. linguiformis Hinde, 1879 s.s. (= gamma morph of authors) has the outer posterior margin adjacent to the tongue developed as a high flange, in contrast with $P$. damelei. For a comparison with the closely related $P$. robertsensis sp. nov., see remarks under the latter.

Stratigraphic range and occurrences. - P. damelei was recorded from the costatus and basal australis zones in the Roberts Mountains. In a specimen we refer to $P$. damelei, Bultynck (1986, pl. 7, fig. 11) reported its occurrence in the partitus Zone from southern Morocco.

\section{Polygnathus aff. $P$. pinguis Weddige, 1977} Figure 14G-I

(aff.) 1977 Polygnathus linguiformis pinguis n. ssp.; Weddige, p. 316 , pl. 5 , figs 88,89 [fig. $89=$ holotype].
Diagnosis. - A species of Polygnathus based on a Pa element with the following combination of characters: wide platform with complete transverse ridges separated from carina on the anterior platform by wide, shallow to somewhat deeper adcarinal troughs (Fig. 14I) that shallow posteriorly and terminate before the tongue; distinct transverse ridges on tongue more closely spaced than those anteriorly; anterior platform margins variable and not parallel; inner margin slightly concave to convex, outer one forms a convex arc; carina slightly curved inwardly, penetrates tongue with a few nodes; outer platform margin lacking a sinus.

Description. - Pa element lower side: small basal pit slightly anterior of platform center; anterior groove open, parallel-sided. Pa element upper side: transverse ridges extend from anterior margins to deep adcarinal troughs; some shorter ridges are intercalated between the ones of normal width; anterior platform margins meet free blade about at a right angle. Free blade about a third of the total unit length, with 4-6 compressed denticles. Unit is strongly arched.

Remarks. - Pa elements of $P$. pinguis Weddige, 1977 differ from $P$. aff. $P$. pinguis by having much wider, shallower adcarinal troughs anterior of the tongue and thus the adjacent transverse ridges are shorter, confined closely to the margins. In $P$. aff. $P$. pinguis there are adcarinal troughs at midlength, as opposed to the narrow adcarinal grooves at midlength in $P$. robertsensis.

Stratigraphic range and occurrences. - In the Roberts Mountains $P$. aff. P. pinguis occurs in the costatus Zone.

\section{Acknowledgements}

S.V.'s research was supported by the Czech-American Cooperation Program (Kontakt ME08011) and the grants of the Czech Geological Survey (333300, 323000, 334000). S.V. was formerly named Stana Berkyová.This is our contribution to IGCP 596. P. Bultynck (Royal Belgian Institute of Natural Sciences) and T. Uyeno (Geological Survey of Canada) are kindly thanked for their meticulous reviews of the manuscript and constructive and helpful remarks. We thank C.A. Sandberg (U.S. Geological Survey, Denver) for significant advice on northern Antelope Range section V and for discussion of costatus Group taxonomy. We are also grateful to Vojtěch Turek, Jan Sklenář, Martin Valent and Rudolf Prokop (Palaeontological department, National Museum, Prague) for facilitation and their kind assistance during photography. Paul Hong (University of California, Riverside) is to be thanked for his help with the photography at the University of California, Riverside. At the University of Iowa, G.K. wishes to thank Neo McAdams and Jonathan Adrain for their excellent help with the Visionary Digital BK Lab System, newly installed in August 2010. M.A.M wishes to thank Thomas G. Morgan, Patrick J. Kennedy and Jeanne D. Power for their kind assistance in the lab and field. 


\section{References}

BARDASHEV, I.A. 1992. Conodont Stratigraphy of Middle Asian Middle Devonian. Courier Forschungsinstitut Senckenberg 154, 31-83.

Bardashev, I.A., Weddige, K. \& Ziegler, W. 2002. The phylomorphogenesis of some Early Devonian Platform conodonts. Senckenbergiana lethaea $82(2), 375-451$. DOI 10.1007/BF03042946

Belka, Z., Kaufmann, B. \& Bultynck, P. 1997. Conodont-based quantitative biostratigraphy for the Eifelian of the eastern Anti-Atlas, Morocco. Geological Society of America Bulletin 109(6), 643-651.

DOI 10.1130/0016-7606(1997)109<0643:CBQBFT>2.3.CO;2

Belka, Z., Klug, C., Kaufmann, B., Korn, D., Doring, S., Feist, R. \& WeNDT, J. 1999. Devonian conodont and ammonoid succession of the eastern Tafilalt (Ouidane Chebbi section), Anti-Atlas, Morocco. Acta Geologica Polonica 49(1), 1-23.

Berkyová, S. 2009. Lower-Middle Devonian (upper Emsian-Eifelian, serotinus-kockelianus zones) conodont faunas from the Prague Basin, Czech Republic. Bulletin of Geosciences 84(4), 667-686. DOI 10.3140/bull.geosci.1153

Bultynck, P. 1970. Révision stratigraphique et paléontologique de la coupe type du Couvinian. Mémoires de l'Institut géologique de l'Université de Louvain 26, 1-152.

BulTYNCK, P. 1986. Lower Devonian (Emsian) - Middle Devonian (Eifelian and lowermost Givetian) conodont successions from the Ma'der and Tafilalt, southern Morocco. Courier Forschungsinstitut Senckenberg 75, 261-286 [date of imprint, 1985].

Carlisle, D., Murphy, M.A., Nelson, C.A. \& Winterer, E.W. 1957. Devonian Stratigraphy of the Sulphur Springs and Pinyon Ranges, Nevada. American Association of Petroleum Geologists, Bulletin 41, 2175-2191.

Chatterton, B.D.E. 1974. Middle Devonian conodonts from the Harrogate Formation, southeastern British Columbia. Canadian Journal of Earth Sciences 11(10), 1461-1484.

Chatterton, B.D.E. 1979. Aspects of late Early and Middle Devonian conodont biostratigraphy of western and northwestern Canada. Geological Association of Canada, Special Paper 18, 161-231 [date of imprint, 1978].

Clark, D.L. \& Ethington, R.L. 1966. Conodonts and biostratigraphy of the Lower and Middle Devonian of Nevada and Utah. Journal of Paleontology 40(3), 659-689.

Elrick, M., Berkyová, S., KlapPer, G., Sharp, Z., JoAChimski, M. \& FRÝDA, J. 2009. Stratigraphic and oxygen isotope evidence for My-scale glaciation driving eustasy in the Early-Middle Devonian greenhouse world. Palaeogeography, Palaeoclimatology, Palaeoecology 276(1-4), 170-181. DOI 10.1016/j.palaeo.2009.03.00

HindE, G.J. 1879. On conodonts from the Chazy and Cincinnati Group of the Cambro-Silurian, and from the Hamilton and Genesse-Shale divisions of Devonian, in Canada and the United States. Quarterly Journal of the Geological Society of London 35, 351-369.

DOI 10.1144/?GSL.JGS.1879.035.01-04.23

Johnson, J.G. 1962. Lower-Middle Devonian boundary in central Nevada. American Association Petroleum Geologists, Bulletin 46, 542-546.

Johnson, J.G. 1966. Middle Devonian brachiopods from the Roberts Mountains, Central Nevada. Palaeontology 9, 152-181.

JoHnson, J.G. 1977. Lower and Middle Devonian faunal intervals in central Nevada based on brachiopods, 16-32. In MURPHY, M.A., BerRy, W.B.N. \& SANDBERG, C.A. (eds) Western North America: Devonian. University of California, Riverside Campus Museum Contributions 4.
Johnson, J.G. \& MuRPhy, M.A. 1984. Time-rock model for Siluro-Devonian continental shelf, western United States. Geological Society of America, Bulletin 95, 1349-1359.

Johnson, J.G., KlAPPER, G. \& ElRick, M. 1996. Devonian transgressive-regressive cycles and biostratigraphy, northern Antelope Range, Nevada: Establishment of reference horizons for global cycles. Palaios 11, 3-14.

Johnson, J.G., KlapPer, G., Murphy, M.A. \& Trojan, W.R. 1986. Devonian Series Boundaries in Central Nevada and neighboring regions, Western North America. Courier Forschungsinstitut Senckenberg 75, 177-196 [date of imprint, 1985].

Johnson, J.G. Klapper, G, \& Trojan, W.R. 1980. Brachiopod and conodont successions in the Devonian of the northern Antelope Range, central Nevada. Geologica et Palaeontologica $14,77-116$

KLAPPER, G. 1971. Sequence within the conodont genus Polygnathus in the New York lower Middle Devonian. Geologica et Palaeontologica 5, 59-79.

KLAPPer, G. 1973. Polygnathus costatus costatus, 347-348. In Ziegler, W. (ed.) Catalogue of Conodonts, Volume I. 504 pp. E. Schweizerbart'sche Verlagsbuchhandlung, Stuttgart.

KLAPPER, G. 1977a. Lower and Middle Devonian conodont sequence in central Nevada; with contributions by D.B. Johnson, 33-54. In Murphy, M.A., Berry, W.B.N. \& SAndberg, C.A. (eds) Western North America: Devonian. University of California, Riverside Campus Museum Contributions 4.

Klapper, G. 1977b. Polygnathus parawebbi, 477-479. In ZIEGLER, W. (ed.) Catalogue of Conodonts, Volume III. 574 pp. E. Schweizerbart'sche Verlagsbuchhandlung, Stuttgart.

KLAPPER, G. \& BARRICK, J.E. 1983. Middle Devonian (Eifelian) conodonts from the Spillville Formation in northern Iowa and southern Minnesota. Journal of Paleontology 57(6), 1212-1243.

KLAPPER, G. \& JohnSON, D.B. 1975. Sequence in conodont genus Polygnathus in Lower Devonian at Lone Mountain, Nevada. Geologica et Palaeontologica 9, 65-83.

KLAPPER, G. \& JoHNSON, J.G. 1980. Endemism and dispersal of Devonian conodonts. Journal of Palaeontology 54(2), 400-455.

Klapper, G. \& Ziegler, W. 1979. Devonian conodont biostratigraphy, 199-224. In House, M.R., Scrutton, C.T. \& Bassett, M.G. (eds) The Devonian System. Special Papers in Palaeontology 23, 1-353.

Klapper, G., Ziegler, W. \& Mashkova, T.V. 1978. Conodonts and correlation of Lower-Middle Devonian boundary beds in the Barrandian area of Czechoslovakia. Geologica et Palaeontologica 12, 103-116.

Kononova, L.I. \& KIM, S.-Y. 2005. Eifelian Conodonts from the Central Russion Platform. Paleontological Journal 39 (Supplement 2), S55-S134.

LANE, R.H. \& ORMiston, A.R. 1979. Siluro-Devonian biostratigraphy of the Salmontrout River area, east-central Alaska. Geologica et Palaeontologica 13, 39-95.

Machado, G., Hladil, J., Slavík, L., Koptíková, L., Moreira, N., FonseCA, M. \& FonseCA, P. 2010. An Emsian-Eifelian Calciturbidite sequence and the possible correlatable pattern of the Basal Choteč event in Western Ossa-Morena Zone, Portugal (Odivelas Limestone). Geologica Belgica 13(4), 431-446.

Mawson, R. 1987. Early Devonian conodont faunas from Buchan and Bindi, Victoria, Australia. Palaeontology 30(2), 251-297.

Mawson, R. \& TALENT, J.A. 1989. Late Emsian-Givetian stratigraphy and conodont biofacies - carbonate slope and offshore shoal to sheltered lagoon and nearshore carbonate ramp - Broken River, north Queensland, Australia. Courier Forschungsinstitut Senckenberg 117, 205-259. 
Mawson, R. \& Talent, J.A. 1994. The Tamworth Group (mid-Devonian) at Attunga, New South Wales: conodont data and inferred ages. Courier Forschungsinstitut Senckenberg 168, 37-59.

Morgan, T.G. 1974. Lithostratigraphy and Paleontology of the Red Hill Area, Eureka County, Nevada. 112 pp. Master of Science in Geology Thesis, University of California, Riverside.

Morrow, J.R. (ed.) 2007. Subcommission on Devonian stratigraphy SDS 2007 field trip guidebook. Devonian Shelf-to-slope facies and events, Central Great Basin, Nevada and Utah, U.S.A. 93 pp. Paleontological Research Institute, Ithaca, NY.

Murphy, M.A. 1977. Middle Devonian rocks of central Nevada, 190-199. In Murphy, M.A., Berry, W.B.N. \& SANDBERG, C.A. (eds) Western North America: Devonian. University of California, Riverside Campus Museum Contributions 4.

Murphy, M.A. \& Gronberg, E.C. 1970. Stratigraphy and correlation of the lower Nevada Group (Devonian) north and west of Eureka, Nevada. Geological Society of America, Bulletin 81, 127-136.

Murphy, M.A. \& Morgan, T.G. 1974. The Denay Limestone, Middle Devonian of Central Nevada. Geological Society of America, Cordilleran Section, Programs with Abstracts.

NARKIEwicz, K. \& Bultynck, P. 2007. Conodont biostratigraphy of shallow marine Givetian deposits from the Radom-Lublin area, SE Poland. Geological Quarterly 51(4), 419-442.

Nasedkina, V.A. \& Plotnikova, N.P. 1979. On Upper Devonian conodonts on the eastern slope of the Northern Ural Mountains, 52-68. In Conodonts of the Ural Mountains and their stratigraphic significance. Ural'skii Nauchnyi Tsentr Akademii Nauk SSSR, Sverdlovsk. [in Russian]

Nolan, T.B., Merriam, C.W. \& Williams, J.S. 1956. The Stratigraphic Section in the Vicinity of Eureka, Nevada. United States Geological Survey, Professional Paper 276, 1-77.

PedDer, A.E.H. 2010. Lower-Middle Devonian rugose coral faunas of Nevada: Contribution to an understanding of the "bar- ren" E Zone and Choteč Event in the Great Basin. Bulletin of Geosciences 85(1), 1-26. DOI 10.3140/bull.geosci.1171

Savage, N. 1977. Middle Devonian (Eifelian) conodonts of the genus Polygnathus from the Wadleigh Limestone, southeastern Alaska. Canadian Journal of Earth Sciences 14, 1343-1355.

SAvAGE, N. 1995. Middle Devonian conodonts from the Wadleigh Limestone, southeastern Alaska. Journal of Paleontology 69(3), 540-555.

Savage, N. 2011. Polygnathus bagialensis, new name for the homonymous $P$. praetrigonicus Savage, 1995, and Polygnathus abbessensis, new name for the homonymous $P$. borealis Savage, 1995 (Conodontes, Polygnathidae). Journal of Paleontology 85(4), 805. DOI 10.1666/11-029.1

SchÖNLAUB, H.P. 1986. Devonian conodonts from section Oberbuchach II in the Carnic Alps (Austria). Courier Forschungsinstitut Senckenberg 75, 353-374 [date of imprint, 1985].

UyenO, T.T. 1998. Part II: Conodont faunas, 146-191. In NorRIS, A.W. \& Uyeno, T.T. Middle Devonian brachiopods, conodonts, stratigraphy, and transgressive-regressive cycles, Pine Point area, south of Great Slave Lake, District of Mackenzie, Northwest Territories. Geological Survey of Canada Bulletin 522.

WANG, C.-Y. \& ZiEgLER, W. 1983. Devonian conodont biostratigraphy of Guangxi, South China, and the correlation with Europe. Geologica et Palaeontologica 17, 75-107.

Weddige, K. 1977. Die Conodonten der Eifel-Stufe im Typusgebiet und in benachbarten Faciesgebieten. Senckenbergiana lethaea 58 (4/5), 271-419.

WitTEKInDT, H. 1966. Zur Conodontenchronologie des Mitteldevons. Fortschritte in der Geologie von Rheinland und Westfalen 9, 621-646 [date of imprint, 1965].

Ziegler, W., Klapper, G. \& Johnson, J.G. 1976. Redefinition and subdivision of the varcus- Zone (Conodonts, Middle-?Upper Devonian) in Europe and North America. Geologica et Palaeontologica 10, 109-140.

\section{Appendix 1}

Species illustrated in this paper, but not formally described in the Systematic section, are listed below with the original, as well as some representative references.

Polygnathus angusticostatus Wittekindt, 1966. Fig. 13J herein.

Polygnathus angusticostata sp. nov. Wittekindt, 1966, p. 631, pl. 1, figs 15-18.

Polygnathus angusticostatus Wittekindt; Klapper, 1971, p. 65, pl. 3, figs 21-25.

Polygnathus angusticostatus Wittekindt, 1966; Weddige, 1977, pp. 306, 307, pl. 6, figs 102-104.

Polygnathus bultyncki Weddige, 1977. Fig. 13H, I herein.

Polygnathus linguiformis Hinde, 1879, alpha forma nova Bultynck, 1970, p. 126, pl. 9, figs 1-7.

Polygnathus linguiformis bultyncki n. ssp. Weddige, 1977, pp. 313, 314, pl. 5, figs 90-92.

Polygnathus linguiformis bultyncki Weddige, 1977; Klapper, Ziegler \& Mashkova, 1978, p. 112, pl. 1, figs 21, 22 , $26-29$.

Polygnathus bultyncki Weddige, 1977; Belka et al., 1999, p. 24, pl. 2, fig. 6.

Polygnathus partitus Klapper, Ziegler \& Mashkova, 1978. Fig. 9C herein.

Polygnathus costatus partitus subsp. nov. Klapper, Ziegler \& Mashkova, 1978, p. 109, pl. 2, Figs 1-5, 13.

Polygnathus costatus partitus Klapper, Ziegler \& Mashkova, 1978; Bultynck, 1986, p. 270, pl. 8, figs 19, $20,22$.

Polygnathus costatus partitus Klapper, Ziegler \& Mashkova, 1978; Berkyová, 2009, pp. 675, 676, figs 5E-I.

Polygnathus patulus Klapper, 1971. Figs 6M, 9A, B herein.

Polygnathus costatus patulus subsp. nov. Klapper, 1971, pp. 62, 63, pl. 1, figs 1-9, 29, pl. 3, figs 16-18.

Polygnathus costatus patulus Klapper, 1971; Weddige, 1977, pp. 310, 311, pl. 4, figs 73, 74.

Polygnathus costatus patulus Klapper, 1971; Klapper, Ziegler \& Mashkova, 1978, p. 14, pl. 2, figs 6-9, 14-17, 19, 20 [figs 25 , 31 transitional with $P$. praetrigonicus Bardashev, 1992].

Polygnathus costatus patulus Klapper, 1971; Bultynck, 1986, p. 270, pl. 8, figs 1-6.

Polygnathus costatus patulus Klapper, 1971; Berkyová, 2009, p. 675, figs 5A-D. 


\section{Appendix 2}

Locality Register with list of conodont samples and their position relative to the base of the Denay Limestone. The asterisk stands for the footage below the base of the Denay Limestone.

\section{Roberts Creek Ranch (RCR) Section Location}

The Middle Devonian part of the RCR Section lies almost exactly 1 mile north slightly northeast of the Roberts Creek Ranch house slightly north of the boundary between sections 18 and 19, T22N, R51E near the southern edge of the Roberts Creek Mountain Quadrangle, 1/62,500, Nevada. It begins at the base of the Denay Limestone a little west of the 6800 foot contour line of the quadrangle map at its contact with the Coils Creek Member of the McColley Canyon Formation on the ridge paralleling the section boundary just to the north of it.

\section{Roberts Creek (RC I) Section Location}

The Roberts Creek Section is very poorly exposed in a northern tributary to Tank Canyon a main western tributary to Roberts Creek two miles north of the Roberts Creek Ranch house, Roberts Creek Mountain Quadrangle, 1/62,500, Nevada. At the head of Tank Canyon, there is a storage tank and watering trough for cattle where the canyon branches into its contributaries. The RC I section is in the north trending gully branching from the main canyon with its lower part in the upper Coils Creek Member of the McColley Canyon Formation and its upper part in the lower Denay Limestone. The section was marked in 1975 but it is not likely that the markings would survive for more than a few years. Resampling would require finding the Coils Creek-Denay contact and measuring away from it.

\section{Willow Creek II (WC II), Willow Creek II North (WC IIN), Willow Creek VI (WC VI) Sections Location}

The WC II section lies on the main ridge leading east from the mouth of Willow Creek to peak 7625. The section begins just below the 10-12 foot cliff at the base of the Denay Limestone which crosses the ridge at about the 7320 foot contour and continues to peak 7625 . Only the lower part of the section from the upper part of the Coils Creek Member of the McColley Canyon Formation through the lower part of the Denay Limestone is discussed in this paper. The WC IIN section is on a subsidiary parallel-trending ridge a short distance to the north of the main ridge and begins at approximately the same level as in the WC II section. WC VI is on the east flank of Willow Creek in a small gully that builds a small fan into Willow Creek where it crosses the 6600 foot contour line on the 1/62500 Roberts Creek Mountain USGS topographic map.

Northern Hot Creek Range, Summit 8782, Morey Peak Quadrangle 1/24,000, Nye County, Nevada

The NHC, Summit 8782 Section is well exposed north and south of the minor peak labeled 8782 on the N-S trending ridge just east of Big Cow Canyon in the middle western third of the Morey Peak 1/24,000 Quadrangle, central Nevada. The section there exposes the McColley Canyon Formation and Denay Limestone and is one of the few sections in Nevada where identifiable dacryoconarids have

\begin{tabular}{|c|c|c|}
\hline $\begin{array}{l}\text { University of California } \\
\text { Riverside Catalog \# }\end{array}$ & $\begin{array}{l}\text { Footage in the WCIIN } \\
\text { Section }\end{array}$ & Murphy Field \# \\
\hline UCR 8697 & $* 0.6^{\prime}(0.18 \mathrm{~m})$ & WCIIN 1 \\
\hline UCR 8698 & $0^{\prime}$ & WCIIN 2 \\
\hline UCR 11052 & $0.2^{\prime}(0.06 \mathrm{~m})$ & WCIIN 2A \\
\hline UCR 8699 & $0.5^{\prime}(0.15 \mathrm{~m})$ & WCIIN 3 \\
\hline UCR 8700 & $13.6^{\prime}(4.5 \mathrm{~m})$ & WCIIN 4 \\
\hline UCR 8702 & $23.6^{\prime}(7.2 \mathrm{~m})$ & WCIIN 5 \\
\hline UCR 8704 & $70.8^{\prime}(21.6 \mathrm{~m})$ & WCIIN 6 \\
\hline UCR 8705 & $74.4^{\prime}(22.7 \mathrm{~m})$ & WCIIN 6A \\
\hline UCR 8706 & $81.7^{\prime}(24.9 \mathrm{~m})$ & WCIIN 6A+4' \\
\hline UCR 8708 & $129.2^{\prime}(39.4 \mathrm{~m})$ & WCIIN 6C-2' \\
\hline UCR 8710 & $139.7^{\prime}(42.6 \mathrm{~m})$ & WCIIN 6D \\
\hline UCR 8712 & $173.8^{\prime}(53 \mathrm{~m})$ & WCIIN 7 \\
\hline UCR 8714 & $205.8^{\prime}(62.7 \mathrm{~m})$ & WCIIN 8 \\
\hline UCR 8714 & $219.8^{\prime}(67 \mathrm{~m})$ & WCIIN 8+14' \\
\hline UCR 8716 & $385^{\prime}(117.4 \mathrm{~m})$ & WCIIN 8C-6' \\
\hline UCR 8721 & $387^{\prime}(118 \mathrm{~m})$ & WCIIN 8G \\
\hline UCR 8722 & $390.4^{\prime}(119 \mathrm{~m})$ & WCIIN 9 \\
\hline UCR 8724 & $525^{\prime}(160 \mathrm{~m})$ & WCIIN 10A2 \\
\hline
\end{tabular}

\begin{tabular}{ll}
\hline Meterage in the NHC Section & Murphy-Klapper Sample Number \\
\hline $24.8 \mathrm{~m}$ & 7 - serotinus Zone \\
$38.5 \mathrm{~m}$ & $8 \mathrm{~A}-$ costatus Zone \\
$63 \mathrm{~m}$ & $10 \mathrm{~A}$ - partitus Zone \\
$64.8 \mathrm{~m}$ & 11 -costatus Zone \\
\hline
\end{tabular}




\begin{tabular}{|c|c|c|}
\hline $\begin{array}{l}\text { University of California } \\
\text { Riverside Catalog \# }\end{array}$ & $\begin{array}{l}\text { Footage in the } \\
\text { RCR Section }\end{array}$ & Murphy Field \# \\
\hline UCR 10983 & $0-0.5^{\prime}(0.152 \mathrm{~m})$ & RCR 12 \\
\hline UCR 10984 & $1^{\prime}(0.305 \mathrm{~m})$ & RCR 12A \\
\hline UCR 10986 & $16^{\prime}(4.87 \mathrm{~m})$ & RCR 14 \\
\hline UCR 10987 & $56.5^{\prime}(17.22 \mathrm{~m})$ & RCR 17 \\
\hline UCR 10988 & $63^{\prime}(19.2 \mathrm{~m})$ & RCR 19 \\
\hline UCR 10989 & $71.5-72^{\prime}(21.8 \mathrm{~m})$ & RCR 22 \\
\hline UCR 11051 & $79.3^{\prime}(24.2 \mathrm{~m})$ & RCR 23 \\
\hline UCR 11019 & $115.8^{\prime}(35.3 \mathrm{~m})$ & RCR 28 \\
\hline UCR 11021 & $126.6^{\prime}(38.5 \mathrm{~m})$ & RCR 30 \\
\hline UCR 11022 & $130.5^{\prime}(39.8 \mathrm{~m})$ & RCR 31 \\
\hline UCR 11023 & $134.5^{\prime}(41 \mathrm{~m})$ & RCR 32 \\
\hline UCR 11054 & $183.7^{\prime}(56 \mathrm{~m})$ & RCR 36 \\
\hline UCR 11031 & $383.8^{\prime}(117 \mathrm{~m})$ & RCR 44A \\
\hline UCR 11032 & $389.7^{\prime}(118.8 \mathrm{~m})$ & RCR 45 \\
\hline UCR 11036 & $492^{\prime}(150 \mathrm{~m})$ & RCR 51 \\
\hline UCR 11035 & $494.7^{\prime}(150.8 \mathrm{~m})$ & RCR 50 \\
\hline $\begin{array}{l}\text { University of California } \\
\text { Riverside Catalog \# }\end{array}$ & $\begin{array}{l}\text { Footage in the } \\
\text { RCR Section }\end{array}$ & Murphy Field \# \\
\hline UCR 8651 & $0^{\prime}$ & H6-1 \\
\hline UCR 8655 & $0.5^{\prime}(0.15 \mathrm{~m})$ & H6-2 \\
\hline UCR 8654 & $65^{\prime}(19.8 \mathrm{~m})$ & WCII 690 \\
\hline UCR 8656 & $66^{\prime}(20.13 \mathrm{~m})$ & WCII 691 \\
\hline UCR 8657 & $136.8^{\prime}(14.7 \mathrm{~m})$ & WCII 762 \\
\hline UCR 8658 & $177.8^{\prime}(42 \mathrm{~m})$ & WCII 763 \\
\hline UCR 8660 & $203.4^{\prime}(62 \mathrm{~m})$ & WCII 828 \\
\hline UCR 8662 & $223^{\prime}(68 \mathrm{~m})$ & WCII 848 \\
\hline UCR 8663 & $225^{\prime}(68.6 \mathrm{~m})$ & WCII 850 \\
\hline UCR 8667 & $283.13^{\prime}(86.3 \mathrm{~m})$ & WCII 900+8' \\
\hline UCR 8668 & $291^{\prime}(88.7 \mathrm{~m})$ & WCII 916 \\
\hline UCR 8669 & $297^{\prime}(88.7 \mathrm{~m})$ & WCII 922 \\
\hline UCR 8671 & $312.2^{\prime}(95 \mathrm{~m})$ & WCII 937 \\
\hline UCR 8675 & $363.2^{\prime}(110.7 \mathrm{~m})$ & WCII 988 \\
\hline
\end{tabular}

\begin{tabular}{|c|c|c|}
\hline $\begin{array}{l}\text { University of California } \\
\text { Riverside Catalog \# }\end{array}$ & $\begin{array}{l}\text { Footage in the WCVI } \\
\text { Section }\end{array}$ & Murphy Field \# \\
\hline UCR 10991 & $0^{\prime}$ & H-32-3, II \\
\hline UCR 10991 & $0^{\prime}$ & H-32-3, II \\
\hline UCR 10991 & $0.5^{\prime}(0.15 \mathrm{~m})$ & $\mathrm{H}-32-3+6^{\prime}$ \\
\hline UCR 10999 & $22.2^{\prime}(6.78 \mathrm{~m})$ & WCVI 2 \\
\hline UCR 11001 & $30.6^{\prime}(9.35 \mathrm{~m})$ & WCVI 4A \\
\hline UCR 11000 & $31^{\prime}(9.5 \mathrm{~m})$ & WCVI 4 \\
\hline UCR 11009 & $41.6^{\prime}(12.7 \mathrm{~m})$ & WCVI 5D \\
\hline UCR 11008 & $35.7^{\prime}(10.9 \mathrm{~m})$ & WCVI 5D-6' \\
\hline UCR 11001 & $42.6^{\prime}(13 \mathrm{~m})$ & WCVI 5C \\
\hline UCR 11012 & $61.3^{\prime}(18.7 \mathrm{~m})$ & WCVI 7A \\
\hline UCR 11012A & $63^{\prime}(19.2 \mathrm{~m})$ & WCVI 8 \\
\hline UCR 11013 & $67.5^{\prime}(20.6 \mathrm{~m})$ & WCVI 9 \\
\hline UCR 11015 & $68.5^{\prime}(20.9 \mathrm{~m})$ & WCVI 9A \\
\hline UCR 11040 & $96.8^{\prime}(29.5 \mathrm{~m})$ & WCVI 10 \\
\hline UCR 11017 & $100.7^{\prime}(30.7 \mathrm{~m})$ & WCVI 9C \\
\hline UCR 11041 & $114.8^{\prime}(35 \mathrm{~m})$ & WCVI 11A \\
\hline UCR 11055 & $149.2^{\prime}(45.5 \mathrm{~m})$ & WCVI 15 \\
\hline UCR 11056 & $156.2^{\prime}(47.6 \mathrm{~m})$ & WCVI $15+7^{\prime}$ \\
\hline UCR 11043 & $173.8^{\prime}(53 \mathrm{~m})$ & WCVI 15A \\
\hline UCR 11044 & $188.3^{\prime}(57.4 \mathrm{~m})$ & WCVI 16A \\
\hline UCR 11045 & $208.3^{\prime}(63.5 \mathrm{~m})$ & WCVI 17 \\
\hline UCR 11046 & $285.4^{\prime}(87 \mathrm{~m})$ & WCVI 19 \\
\hline UCR 11047 & $293.6^{\prime}(89.5 \mathrm{~m})$ & WCVI 21 \\
\hline UCR 11049 & $504.2^{\prime}(153.7 \mathrm{~m})$ & WCVI 27A \\
\hline UCR 11050 & $506.2^{\prime}(154.3 \mathrm{~m})$ & WCVI 27B \\
\hline $\begin{array}{l}\text { University of California } \\
\text { Riverside Catalog \# }\end{array}$ & $\begin{array}{l}\text { Footage in the RCI } \\
\text { Section }\end{array}$ & Murphy Field \# \\
\hline UCR 10967 & $* 14.8^{\prime}(4.5 \mathrm{~m})$ & RCI 2 \\
\hline UCR 10968 & $* 3.28^{\prime}(1 \mathrm{~m})$ & RCI 3 \\
\hline UCR 10969 & $0^{\prime}$ & RCI 4 \\
\hline UCR 10970 & $2.6^{\prime}(0.8 \mathrm{~m})$ & RCI 5 \\
\hline UCR 10971 & $11.5^{\prime}(3.5 \mathrm{~m})$ & RCI 6 \\
\hline UCR 11053 & $36.7^{\prime}(11.2 \mathrm{~m})$ & RCI 14 \\
\hline
\end{tabular}

been recovered. A columnar diagram and the distribution of conodont species were shown for the Summit 8782 section in Johnson et al. (1986, fig. 7, table 8). A revision here is that sample 10A is now interpreted as being in the partitus Zone. A fault is recognized between the part of the section containing samples 7, 8A and that containing samples 10A, 11. These four samples provided specimens illustrated in the present study.

\section{Northern Antelope Range, section V}

Northern edge of NE1/4 sec. 21, T. 16 N., R.51 E., southern Eureka County, Nevada. Position of section and columnar diagrams are shown in Johnson et al. (1980, 1986, 1996). Distribution of conodont species is shown in Johnson et al. (1996, table 2). Several critical zonal identifications have changed since that paper, as noted by C.A. Sandberg and G. Klapper in Elrick et al. (2009, p. 171). Samples VH 6-9 are now known to belong to the partitus Zone, which closely overlies the serotinus Zone represented by sample VH-5. Samples that provided illustrated specimens for the present study are VH-5, 8, VG-25, SB-26, VB-3, and VH-32. Stratigraphic position of these samples is given in Johnson et al. (1996, table 2). 


\section{Appendix 3}

Table showing occurrences of conodont species with the number of specimens indicated. $<5=\bullet, 5-10=0,11-20=\mathbf{\square}, 21-30=\square$, $>30=x$.

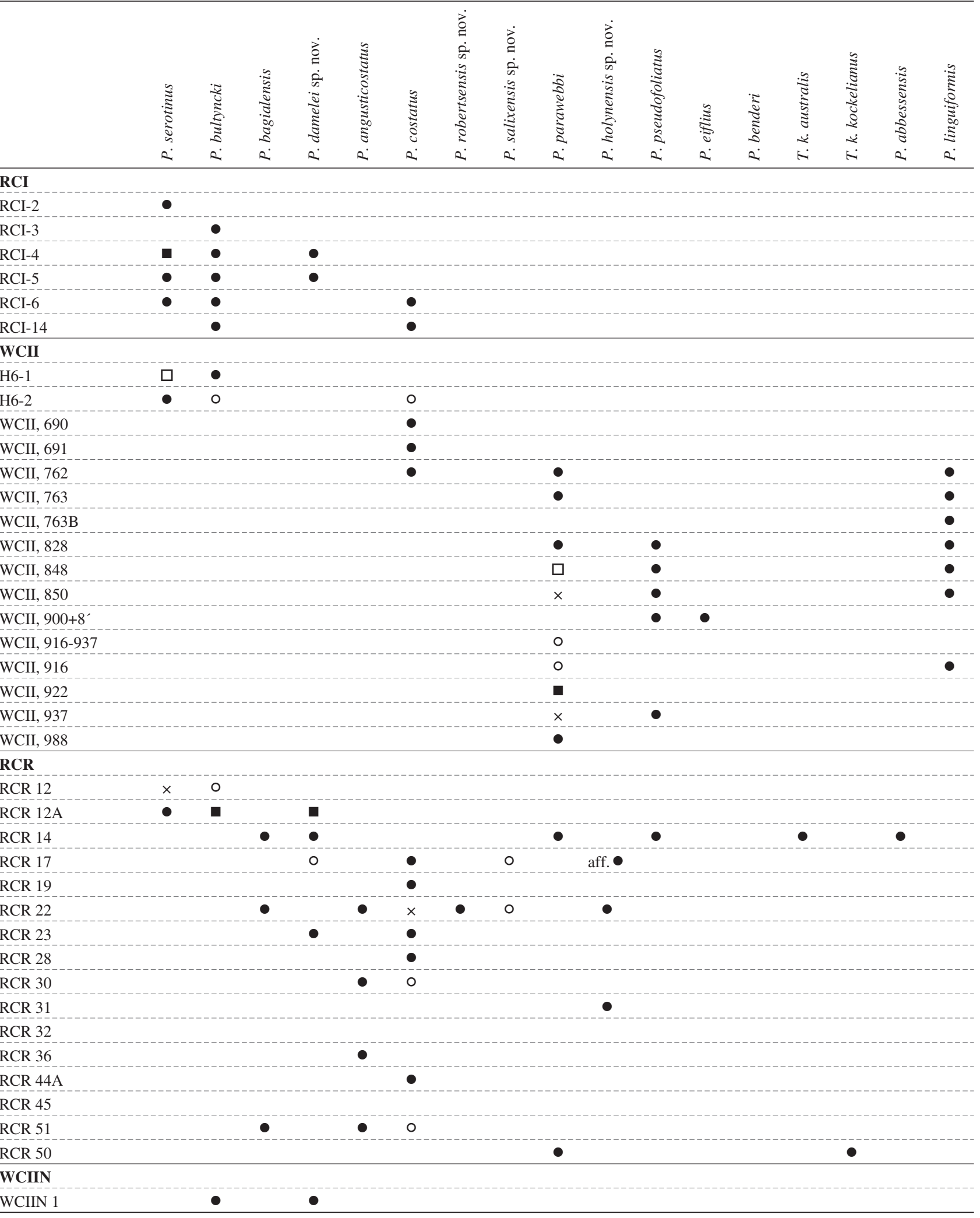




\begin{tabular}{|c|c|c|c|c|c|c|c|c|c|c|c|c|c|c|c|c|c|}
\hline & 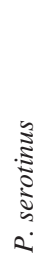 & 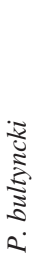 & 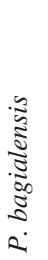 & 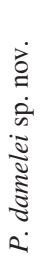 & 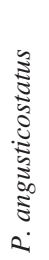 & 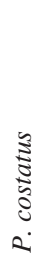 & 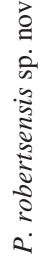 & 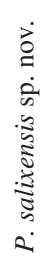 & 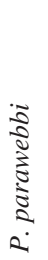 & 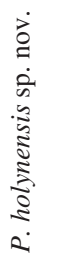 & 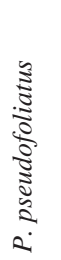 & 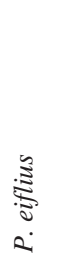 & 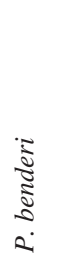 & 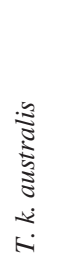 & 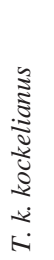 & 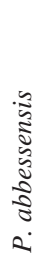 & 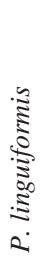 \\
\hline WCIIN 2 & & 0 & & & & $\bullet$ & & & & & & & & & & & \\
\hline WCIIN 2A & 0 & 0 & & & & $\bullet$ & & & & & & & & & & & \\
\hline WCIIN 3 & 0 & $\bullet$ & & & & $\bullet$ & & & $\bullet$ & & & & & & & & $\bullet$ \\
\hline WCIIN 4 & & & & & & $\bullet$ & & & $\bullet$ & & & & & & & & $\bullet$ \\
\hline WCIIN 5 & & & & - & & 0 & 0 & & & & & & & & & & - \\
\hline WCIIN 6 & $\bullet$ & & & & & 0 & & & $\bullet$ & & $\bullet$ & & & & & & $\bullet$ \\
\hline WCIIN 6A & & & & & & & & & $\square$ & & $\bullet$ & & & & & & $\bullet$ \\
\hline WCIIN $6 \mathrm{~A}+4$ & & & $\bullet$ & & - & - & & & $x$ & $\bullet$ & $\bullet$ & & & & & & $\bullet$ \\
\hline WCIIN 6C-2' & & & & & & & & & & & $\bullet$ & $\bullet$ & & & & & \\
\hline WCIIN 6D & & $\bullet$ & & & $\bullet$ & & & & o & & & & & & & & \\
\hline WCIIN 7 & & & & & & & & & o & & & & & & & & $\bullet$ \\
\hline WCIIN 8 & & & & & & & & & - & & & & & & & $\bullet$ & \\
\hline WCIIN 8+14' & & & $\bullet$ & & & & & & $\times$ & & & & - & & & $\bullet$ & $\bullet$ \\
\hline WCIIN 8G-6' & & & & & & & & & $\bullet$ & & & & & & & & \\
\hline WCIIN $8 \mathrm{G}$ & & & & & & & & & $\times$ & & $\bullet$ & & & & & & \\
\hline WCIIN 9 & & & & & & & & & $\bullet$ & & & & & & & & \\
\hline WCIIN 10A2 & & & & & & & & & $\square$ & & & & & & & & $\bullet$ \\
\hline \multicolumn{18}{|l|}{ WCVI } \\
\hline H32-3, II & $\times$ & & & & & & & & $\bullet$ & & & & & & & & \\
\hline H32-3, I & & 0 & & $\bullet$ & & & & - & & & & & & & & & \\
\hline WCVI, H32-3+6 & 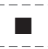 & 0 & & 0 & & $\bullet$ & & & & & & & & & & & \\
\hline WCVI XVI & & - & $\bullet$ & & & & & $\bullet$ & & & & & & & & & \\
\hline WCVI 2 & & 0 & & 0 & & $\times$ & & & & & & & & & & & \\
\hline WCVI 3D & & & & & & $\bullet$ & & & & & & & & & & & \\
\hline WCVI 4A & & $\bullet$ & & $\square$ & & a & & $\square$ & & & & & & & & & \\
\hline WCVI 4A & & & & & & $\bullet$ & & & & & & & & & & & \\
\hline WCVI 5D & & & & & & $\bullet$ & & 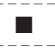 & & & & & & & & & \\
\hline WCVI 5D-6' & & & & & & $\bullet$ & & & & & & & & & & & \\
\hline WCVI 5C & & & & 0 & $\bullet$ & $\bullet$ & & $\square$ & & & & & & & & & \\
\hline WCVI 7A & & & & & $\bullet$ & 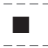 & & & & & & & & & & & \\
\hline WCVI 8 & & & & $\bullet$ & & $\bullet$ & & & & & & & & & & & \\
\hline WCVI 9 & & & & & & 0 & & & & & & & & & & & \\
\hline WCVI 9A & & & & & $\bullet$ & $x$ & & & & & & & & & & & \\
\hline WCVI 10 & & & & & $\bullet$ & $\bullet$ & & & & & & & & & & & \\
\hline WCVI 9C & & & & & & $\bullet$ & & & & & & & & & & & \\
\hline WCVI 11A & & & & & $\bullet$ & & & & $\bullet$ & & & & & & & & \\
\hline WCVI 15 & & & & & & & & & $\bullet$ & & & & & & & & \\
\hline WCVI $15+7$ & & & & & & & & & $\bullet$ & & & & & & & & \\
\hline WCVI 15A & & & & & & & & & $\bullet$ & & & & & & & & $\bullet$ \\
\hline WCVI 16A & & & & & & $\bullet$ & & & $\bullet$ & & & & $\bullet$ & & & $\bullet$ & \\
\hline WCVI 17 & & & & & & & & & 0 & & $\bullet$ & & & $\bullet$ & & $\bullet$ & \\
\hline WCVI 19 & & & & & & & & & & & & & & & & & $\bullet$ \\
\hline WCVI 21 & & & & & & & & & & & & & $\bullet$ & & & & \\
\hline WCVI $27 \mathrm{~A}$ & & & & & & & & & o & & & & & & & & \\
\hline WCVI $27 \mathrm{~B}$ & & & & & & & & & 0 & & & & & & & & \\
\hline
\end{tabular}

